\title{
Politics and the Rule of Law in Transnational Judicial Governance: The Case of Forum Non Conveniens
}

\author{
Christopher A. Whytock \\ Department of Political Science \\ Duke University \\ chris.whytock@duke.edu \\ Preliminary Draft: \\ February 28, 2007
}

\begin{abstract}
Domestic courts play an important role in the regulation of transnational economic activity, which I refer to as "transnational judicial governance." However, because judicial politics scholars have focused primarily on matters of domestic policy and international relations scholars have virtually ignored domestic legal institutions, we have very little knowledge about how domestic courts behave as global governors and why. In particular, are the determinants of domestic court decisionmaking in transnational judicial governance primarily political, as leading theories of judicial decisionmaking and international relations would suggest? Or, given the distinct nature of domestic courts as legal institutions, is transnational judicial governance instead based on the rule of law? To answer this question, this paper focuses on one important example of transnational judicial governance decisionmaking: the choice between the assertion of domestic adjudicative authority and deference to foreign adjudicative authority over transnational activity based on the doctrine of forum non conveniens. Drawing on theories of judicial decisionmaking, international relations, private international law, and bounded rationality, and using statistical and qualitative analysis of an original dataset of over 200 forum non conveniens decisions in U.S. district courts, I test a series of hypotheses about the political and rule-of-law factors that determine the choice between domestic and foreign adjudicative authority. I find that rule-of-law factors predominate. Although U.S. district court judges are more likely to defer to foreign governance authority if the foreign state is a liberal democracy, Republican judges are no less likely than Democratic judges to defer to foreign governance authority; and the most important factor appears to be the use of a particular decisionmaking shortcut or "heuristic" that allows judges to make legally competent choices between domestic and foreign authority while conserving scarce decisionmaking resources.

For helpful comments and criticisms on earlier versions of this paper and the broader project of which this paper is a part, I thank Mark Axelrod, Paul Schiff Berman, Peggy McGuinness, Tim Büthe, Matthew Fehrs, Mitu Gulati, Bruce Jentleson, Judith Kelley, Ralf Michaels, Imke RisoppNickelson, Jenia Iontcheva Turner, Camber Warren, and David Zaring.
\end{abstract}

Comments welcome. 


\section{Politics and the Rule of Law in Transnational Judicial Governance: The Case of Forum Non Conveniens}

\section{Introduction}

How do states regulate transnational economic activity? International relations and international legal scholars have emphasized the role of international institutions as tools of global governance, giving rise to a rich literature on the origins and consequences of international organizations and international rules. ${ }^{1}$ However, this preoccupation with international institutions obscures the fact that domestic institutions also play a central role in state regulation of transnational activity. For example, states often address transnational problems through transgovernmental networks, which involve direct cross-border interactions among national regulatory agencies (Keohane and Nye 1974; Raustiala 2002; Slaughter 2004; Slaughter and Zaring 2006; Whytock 2005). In addition, international political economists have shown that domestic executive and legislative institutions are key players in "two-level games," according to which solutions to international cooperation problems must be negotiated not only among states, but also among domestic political actors within each state (Evans, Jacobson, and Putnam 1993; Frieden and Martin 2002, 120-126; Putnam 1988).

This paper focuses on the regulation of transnational activity by domestic courts, which I call "transnational judicial governance" (Whytock 2006b). Thousands of disputes arising out of transnational economic activity are heard each year in U.S. federal courts alone. Substantively, these decisions allocate economic resources among transnational actors. Jurisdictionally, they allocate governance authority among states_-for example, by determining whether a domestic court or a foreign court should adjudicate a dispute, whether domestic or foreign law should be applied to govern the underlying transnational activity, and whether the decisions of foreign courts in transnational disputes should be given domestic effect. Moreover, when domestic courts publish their decisions in transnational litigation, they not only directly affect the litigants; they also provide information about how they are likely to decide similar cases in the futureinformation that can indirectly influence the strategic behavior of transnational actors beyond a particular dispute. Domestic courts are, in effect, global governors.

Because transnational judicial governance involves the allocation of resources and authority, its consequences are intrinsically political. But do domestic courts make these allocative decisions in the same way as other global governors? Leading theories of judicial decisionmaking and international relations suggest that courts, like other political actors, base their decisions primarily on political considerations such as ideology and power. These theories imply that the determinants as well as the consequences of transnational judicial governance are political. Alternative theories of judicial decisionmaking emphasize the distinctive nature of courts as legal institutions. These theories imply that transnational judicial governance is based on the rule of law more than politics. The normative implications of these two visions of

\footnotetext{
${ }^{1}$ For overviews of this expansive body of literature, see Martin and Simmons (1998) and Keohane and Martin (2003). Recent contributions by international relations scholars include Gruber (2000), Ikenberry (2001), Koremenos, Lipson and Snidal (2001), Simmons (2000), Simmons and Hopkins (2005) and Von Stein (2005). Recent contributions by international legal scholars include Norman and Trachtman (2005), Goldsmith and Posner (2005) and Raustiala (2005).
} 
transnational judicial governance may be self-evident. But empirical research on the role of domestic courts in global governance is almost entirely lacking. International relations scholars have virtually ignored domestic courts, ${ }^{2}$ judicial politics scholars have focused primarily on matters of domestic policy, ${ }^{3}$ and legal scholars have engaged in little positive theoretical and empirical work on transnational litigation. ${ }^{4}$ As a result, we have very little knowledge about how domestic courts behave as global governors and why. In particular, we are left with an open question: Does politics or the rule of law predominate in transnational judicial governance?

This paper attempts to shed some empirical light on this question, and it does so in an interdisciplinary manner, using theories of judicial politics, international relations, private international law, and bounded rationality. Part 2 lays the conceptual foundations, explaining the role of domestic courts in the regulation of transnational activity and highlighting an important dimension of variation in transnational judicial governance decisionmaking: assertion of domestic governance authority versus deference to foreign governance authority over transnational activity. Part 3 introduces the theoretical priors that inform the political and ruleof-law visions of transnational judicial governance, deriving from them hypotheses about factors affecting the probability that a domestic court will defer to foreign governance authority instead of asserting domestic governance authority in a given case. Part 4 describes the data and methods used to test these hypotheses, which include statistical and qualitative analysis of an original dataset of over 200 U.S. district court decisions on motions to dismiss transnational litigation under the forum non conveniens doctrine-decisions in which courts explicitly choose between domestic and foreign authority to adjudicate transnational disputes. Part 5 presents my results, and Part 6 discusses the broader implications of my findings.

\section{The Concept of Transnational Judicial Governance}

Transnational judicial governance is the regulation of transnational activity by domestic courts. The principal mechanism of transnational judicial governance is transnational litigation, by which I mean litigation in domestic courts arising from activity with territorial or legal connections to more than one state. ${ }^{5}$ Between 1995 and 2005, an average of 3,285 cases per year based on diversity jurisdiction and involving at least one foreign party were terminated in U.S. district courts alone. ${ }^{6}$ The subject matter of these disputes is as diverse as transnational activity

\footnotetext{
${ }^{2}$ Exceptions include Burley (1992), Putnam (2006), Raustiala (2006), Slaughter (1994, 2004, chap. 2), and Whytock (2006a, 2006b, 2006c). In addition, some international relations scholars have highlighted the role of domestic courts in European integration, including Alter (2001), Burley and Mattli (1993), and Stone Sweet and Brunell (1998),

${ }^{3}$ Exceptions include studies on U.S. federal court decisionmaking in matters involving human rights (Davis 2006) and international trade (Unah 1998).

${ }^{4}$ Exceptions include Clermont and Eisenberg's (1996) study of foreign parties in U.S. courts.

${ }^{5}$ Hannah Buxbaum (2006) and Robert Wai (2002, 2005a, 2005b) are among those who have most thoroughly explored the global governance implications of transnational litigation. Slaughter (1994, 2004, chap. 2) describes cross-border interactions among judges through transgovernmental networks, which might be understood as another mechanism of transnational judicial governance. However, the most common forms of transnational judicial governance occur outside the context of such networks. Although important—and perhaps of growing importance-I do not include in my definition private forms of transnational dispute resolution, such as arbitration (Dezalay and Garth 1996; Mattli 2001; Stipanowich 2004; Stone Sweet 2006).

${ }^{6}$ This is based on my analysis of data obtained from the Federal Judicial Center. Diversity of citizenship of the parties is only one basis for U.S. federal court jurisdiction over transnational disputes. This figure excludes
} 
itself, ranging from international business to cross-border environmental damage, from economic regulation to human rights, and from intellectual property to international terrorism. Although most of these disputes are between nonstate actors, state actors are frequently involved. For example, between 1995 and 2005, an average of 475 diversity cases per year in U.S. district courts involved a foreign sovereign. ${ }^{7}$

\subsection{The Allocative Functions of Transnational Judicial Governance}

At the core of transnational judicial governance are two allocative functions. Substantively, most transnational litigation involves matters of domestic private law, including the law of property, contracts, and torts. These fields of private law are policy instruments by which states authoritatively allocate economic resources (Cooter and Ulen 2000; Kaplow and Shavell 1999; Shapiro 1972), and in transnational litigation they serve both distributive and regulatory functions (Wai 2005b, 247-249). Disputes over property rights-including intellectual property rights-explicitly involve conflicting claims over economic resources. In such disputes, domestic courts allocate those resources by assigning property rights to one party or another. Transnational actors enter contracts to reduce their uncertainty about how they will share the costs and benefits of their economic transactions. In contract disputes, domestic courts allocate these costs and benefits by determining how the contract is interpreted and whether it is enforced. Transnational economic activity may generate externalities; that is, it may have effects on an actor who does not have a contractual relationship with the person engaged in that activity. In tort disputes, domestic courts allocate the costs of negative externalities among transnational actors by determining the extent to which the party generating the externalities must compensate the party that bears the associated costs. In these ways, when domestic courts apply private law to resolve transnational disputes, they allocate economic resources among transnational actors.

The second allocative function of transnational judicial governance-the allocation of governance authority among states-arises from the distinct nature of transnational activity. Because such activity has connections to more than one state, more than one state may have a basis for legitimately exercising the authority to govern it. The challenge is that "law has become the prerogative of territorial sovereigns, whereas human affairs freely cross . . . national boundaries” (Juenger 2005, 3). Three basic types of governance authority are at stake: adjudicative authority, which is the authority of a state to use its courts to resolve disputes involving particular actors or things; prescriptive authority, which is the authority of a state to apply its law to particular actors or activities; and enforcement authority, which is the authority of a state to induce or compel compliance with its law (Carter and Trimble 1991, 699-702).

In transnational litigation, domestic courts are routinely called upon to decide how to allocate these three types of authority, and these decisions share a common domestic-foreign dimension of variation: each decision is either an assertion of domestic authority to govern the underlying transnational activity, or deference to a foreign state's authority to govern that

transnational disputes (a) that are brought in federal courts based on jurisdictional grounds other than diversity (e.g. federal question jurisdiction), (b) that do not involve a non-U.S. party, (c) that are brought in U.S. state courts or (d) that are brought in non-U.S. courts. Therefore, this figure only offers an estimate of the minimum number of transnational disputes in domestic courts each year.

${ }^{7}$ My analysis of Federal Judicial Center data. 
activity. ${ }^{8}$ For example, imagine a dispute arising out of activity with connections to both State A and State B. If the plaintiff brings the dispute before a State A court, should the State A court adjudicate the dispute (assertion of domestic adjudicative authority) or should it dismiss the case so it can be adjudicated by a State B court (deference to foreign adjudicative authority)? If a State A court decides to adjudicate the dispute, should it apply State A law to the underlying transnational activity (assertion of domestic prescriptive authority) or should it apply State B law (deference to foreign prescriptive authority)? And if a State B court adjudicates the dispute, one party may ask a State A court to enforce the State B court's judgment against the other party in State A. Should the State A court refuse to do so (thus asserting the territorial exclusivity of domestic enforcement authority) or should it give domestic effect to the foreign judgment (thus deferring to foreign enforcement authority)?

International legal scholars commonly use the term "allocation” to refer to the distribution of adjudicative, prescriptive and enforcement authority among states (Carter and Trimble 1991, 699-700; Reisman, Arsanjani, Wiessner, and Westerman 2004, 1381-1383; Sweeney, Oliver, and Leech 1988, 82-83). However, given the highly decentralized nature of transnational judicial governance, it must be understood that individual domestic courts cannot unilaterally allocate that authority. Even if a State A court asserts its own governance authority over a particular transnational activity, it cannot prevent State B from also asserting authority over that activity; as Scoles, Hay, Borchers and Symeonides (2004, 2) point out, there is not "an impartial mechanism of hierarchically superior authority for resolving such conflicts.”

Conversely, even if State A defers to State B's governance authority, it cannot compel State B to exercise that authority. How authority actually is allocated ultimately is the aggregate result of decisions by courts of multiple states. Thus, authority allocation generally should be understood as a collective function, although not necessarily a coordinated function, of transnational judicial governance.

The essential point is that, by deciding between the assertion of domestic governance authority and deference to foreign governance authority over transnational activity, domestic courts help define the domestic reach of foreign authority and the foreign reach of domestic authority. Or, to use Krasner's $(1999,22)$ terminology, they help define the circumstances in which Westphalian sovereignty is compromised "through invitation."9 As Reisman et al. (2004, 1381) put it, lawyers may "refer to these encounters as 'conflicts of laws,' but they are, in the

\footnotetext{
${ }^{8}$ To clarify, by “deference” I mean, at a minimum, a decision by a State A court not to assert State A's governance authority, coupled with an affirmation that, under the circumstances, it is appropriate for State B to exercise its authority. Thus, deference implies an understanding by State A that authority should be allocated to State B. The term does not, however, imply that State B is necessarily interested in exercising that authority. For example, a State A court may defer to State B's adjudicative authority by declining to exercise its own adjudicative authority over a lawsuit originally brought in the State A court and dismissing it in favor of a State B court; but State B may or may not actually exercise its authority. On the other hand, declining to assert domestic authority without a corresponding affirmation of a foreign state's authority is mere abstention, not deference, and does not imply an understanding of the appropriate allocation of governance authority. Deference also may be more active. For example, a State A court may defer to State B's prescriptive authority by applying State B's law to transnational activity, and a State A court may defer to State B's enforcement authority by ordering the enforcement within State A territory of a judgment of a State B court.

${ }^{9}$ According to Krasner, the institution of Westphalian sovereignty is based on territoriality and the exclusion of external authority $(1999,20)$. The invitation of foreign authority does not violate international legal sovereignty because it is voluntary, but it does violate Westphalian sovereignty $(1999,22)$.
} 
most profound sense, conflicts of power, for they engage the very essence of state sovereignty: a state’s exercise of its political power by making and applying its law.”

\subsection{Direct and Indirect Effects of Transnational Judicial Governance}

Transnational judicial governance has direct and indirect implications for transnational activity. For the parties to a particular transnational dispute, the allocative consequences of a domestic court's decision are direct. These direct effects are the focus of litigant-oriented approaches to the study of litigation. Without discounting the importance of litigation outcomes for individual litigants, the concept of transnational judicial governance is intended to draw attention to the broader indirect consequences of judicial decisionmaking in transnational litigation. The behavior of transnational actors depends not only on their preferences, but also on their beliefs about what other actors will do (Lake and Powell 1999, 8-11), including governmental actors such as courts. As Stone Sweet and Brunell $(1998,64)$ explain, "When a judge decides, the lawmaking effect of the decision is always twofold. First, in settling the dispute at hand, the judge produces a legal act that is particular (it binds the two disputants) and retrospective (it resolves an existing dispute). Second, in justifying the decision, the judge signals that she will settle similar cases similarly in the future; this legal act is a general and prospective one (it affects future and potential contractants)." 10 In other words, when a domestic court publishes decisions that allocate economic resources or governance authority in a particular dispute, it shapes the expectations that transnational actors have about how it will decide similar allocative issues under similar circumstances in the future, thus influencing their strategic behavior.

That the impact of substantive court decisions in particular disputes can extend well beyond the parties to those disputes is well understood-this is the phenomenon of strategic behavior "in the shadow of the law" (Busch and Reinhardt 2000; Cooter, Marks \& Mnookin 1982; Cooter and Ulen 2000). The same is true for decisions that allocate governance authority. For example, because transnational activity has connections to more than one state, actors may be uncertain about which state's laws are applicable to their cross-border activities. When domestic courts make decisions allocating prescriptive authority in a particular case, they provide information about applicable law that makes it more likely that transnational actors will conform their conduct to the law of one state or another. Similarly, jurisdictional decisions provide information that influences "forum shopping" by transnational actors. When deciding where to file their lawsuits, plaintiffs consider, among other things, which state's laws are most favorable to their claim. For example, if the plaintiff is more likely to win under State A's law than under State B's law, the plaintiff may file its lawsuit in a State A court, even if the transnational activity giving rise to the dispute occurred primarily in State B. Prior State A court decisions in similar circumstances applying the law of the place of the underlying transnational activity rather than its own law would discourage this form of forum shopping, as would State A

\footnotetext{
${ }^{10}$ As Sandholtz and Stone Sweet $(2004,245)$ explain, “a norm can prevent disputes from arising in the first place, by providing individuals with behavioral guidance, and by structuring choices concerning compliance. ... . [O]nce a dispute has erupted, norms may provide the contracting parties with the materials for settling the dispute on their own, dyadically as it were, to the extent that norms furnish the bases for evaluating both the disputed behavior and potential solutions to the conflict.”
} 
court decisions dismissing similar cases that arise from activity occurring outside State A territory. $^{11}$

More generally, transnational judicial governance indirectly affects transnational activity by either facilitating or hindering alternative approaches to global governance. For example, by applying international law to transnational disputes, domestic courts enhance the effectiveness of formal interstate governance arrangements; by declining to do so, they limit the effectiveness of these arrangements. Similarly, domestic courts can support private governance by enforcing contracts. Transnational activity generates transnational conflict which in turn creates a demand for transnational third-party dispute resolution (Stone Sweet and Brunell 1998, 63-64). Without third-party dispute resolution, "the costs of exchanges may be prohibitive, since each prospective party may doubt that the other will abide by promises made over the life of a contract" (Stone Sweet and Brunell 1998, 64). By providing transnational dispute resolution services, domestic courts help meet this demand, providing an important global public good that enhances contracting as a form of private governance. Similarly, domestic courts can support arbitration as a form of private dispute resolution by enforcing arbitration agreements and arbitral decisions - or they can undermine it by declining to do so. As Slaughter $(1995,519)$ puts it, "the availability of judicial enforcement - the coercive apparatus of the State-undergirds the entire system of international commercial arbitration.”

\section{Transnational Judicial Governance: Politics or Rule of Law?}

The concept of transnational judicial governance draws attention to the role of domestic courts in allocating governance authority among states. But under what circumstances do domestic courts defer to foreign authority to govern transnational activity instead of asserting domestic governance authority? What, in other words, explains the domestic-foreign dimension of variation in transnational judicial governance? Because they allocate authority, the implications of these decisions are intrinsically political. But are the determinants of these decisions also political? Or, because judges are the decisionmakers, are these decision instead based on legal considerations? As Robert Wai (2005b, 251) asks in his insightful discussion of the global governance implications of transnational litigation, "Do the distinctive politics of adjudication . . . translate into the possibility that adjudication of transnational disputes by national courts might follow a different logic than the dominant logic of world politics . . . ?” I pose this as a question about international relations-namely, about how governance authority is allocated among states. However, because domestic court judges are the decisionmakers in transnational judicial governance, I treat the judge rather than the unitary state as the primary unit of my analysis. And because it is the behavior of judges that I am trying to explain, I reach outside traditional international relations theory and take the political science literature on judicial decisionmaking as my theoretical starting point. ${ }^{12}$

\footnotetext{
${ }^{11}$ For discussions of how rules allocating adjudicative and prescriptive authority can affect strategic behavior, see Brilmayer (1991, 167-175), O’Hara and Ribstein (1999, 634-635), and Whincop and Keyes (26-30).

${ }^{12}$ This follows Milner's (1998) call for international relations scholars to relax the unitary state assumption in their work. So far, however, this rarely has been done to focus on the role of domestic courts in international relations (for exceptions, see Putnam (2006) and Whytock (2006a, 2006b, 2006c)).
} 


\subsection{Politics in Transnational Judicial Governance}

The leading theories of judicial decisionmaking would suggest that domestic court decisionmaking in transnational judicial governance is driven above all by political factors. According to the attitudinal model, court decisions are based on judges' personal policy preferences (Rohde and Spaeth 1976; Spaeth 1995; Segal and Spaeth 2002). The attitudinal model assumes that "the primary goals of Supreme Court justices in the decision-making process are policy goals. Each member of the Court has preferences concerning the policy questions faced by the Court, and when the justices make decisions they want the outcomes to approximate as nearly as possible those policy preferences” (Rohde and Spaeth 1976, 72). Judges, in other words, are "policy maximizers." It also assumes that the American political system gives the justices "enormous latitude" to reach decisions based on these preferences: they have life tenure, "lack electoral or political accountability, have no ambition for higher office, and comprise a court of last resort that controls its own caseload” (Segal and Spaeth 2002, 92).

Based on these assumptions, the attitudinal model posits "that the justices decide their cases on the basis of the interaction of their ideological attitudes and values with the facts of the case. Justice William J. Brennan, Jr., decided cases as he did because he was liberal; Justice William Rehnquist or Warrant Burger, because they were conservative. In other words, the justices vote as they do because they want their decisions to reflect their individual policy preferences” (Spaeth 1995, 305). Assuming that conservative judges are less likely to defer to foreign governance authority than liberal judges, ${ }^{13}$ one might plausibly derive from the attitudinal model the following hypothesis:

Attitudinal Model Hypothesis (H1): A conservative judge is less likely to defer to foreign governance authority than a liberal judge.

The strategic model of judicial decisionmaking shares the attitudinal model's basic assumption that Supreme Court justices are policy maximizers, positing that "justices, first and foremost, wish to see their policy preferences etched into law. They are . . . 'single-minded seekers of legal policy"” (Epstein and Knight 1998, 9-10). However, in contrast to the attitudinal model's emphasis on justices' “enormous latitude” to make decisions based on their personal preferences, the strategic model emphasizes the constraints that justices face. To maximize their preferences, justices must act strategically; that is, they must consider not only their own

\footnotetext{
${ }^{13}$ While not self-evident, this assumption seems plausible in light of recent survey work conducted by the Pew Research Center for the People and the Press (2005a, 2005b). Of most direct relevance, Republicans overall were more likely than Democrats to agree that the United States should follow its own national interests even when its allies strongly disagree, and less likely than Democrats to agree that U.S. foreign policy should take into account the interests and views of allies (2005a, 21), which is consistent with the assumption that conservatives are less likely to defer to foreign governance authority. However, only the most ideologically driven groups within each party expressed views that differ significantly from the national average (2005a, 21). The partisan divide was more pronounced on other matters that may have a bearing on the likelihood of deference to foreign governance authority. For example, Republicans were less likely than Democrats to agree that "[t]he U.S. should mind its own business internationally and let other countries get along the best they can on their own” (2005b, 42). In addition, Republicans were less likely than Democrats to have confidence in diplomacy (2005a, 21) and less likely than Democrats to agree that the U.S. "should cooperate fully with the United Nations" (2005b, 42) —attitudes which seem consistent with less willingness on the part of Republicans to defer to foreign governance authority.
} 
preferences, but also the preferences and actions of other political actors such as Congress, the president, and the public, with which the achievement of justices' policy goals are interdependent (Epstein and Knight 1998, 12). Simply put, "the choices of justices can best be explained as strategic behavior, not solely as responses to either personal ideology or apolitical jurisprudence” (Epstein and Knight 1998, xiii).

An important implication of the strategic model is the political environment has an influence on judicial decisionmaking. Congress and the president have a "vast array of powers over matters important to the Court” (George and Epstein 1992, 325). For example, Congress can propose constitutional amendments or pass legislation overriding court decisions. It also can use judicial salaries, impeachment, or legislative limits on jurisdiction to "punish" justices for their decisions - and although this rarely occurs, the possibility of such measures gives justices an incentive to consider the policy preferences of the other branches (Epstein and Knight 1998, 141-143). In addition, "government actors can refuse, implicitly or explicitly, to implement particular constitutional decisions, thereby decreasing the Court's ability to create efficacious policy" (Epstein and Knight 1998, 144). Thus, the strategic model suggests that "Congress and the president affect Supreme Court decision making and that the direction of their influence reflects their partisan composition” (George and Epstein 1992, 325). Again assuming that conservatives are less likely than liberals to prefer deference to foreign governance authority, the following hypothesis can be derived from the strategic model of judicial decisionmaking:

Strategic Model Hypothesis (H2): A judge is less likely to defer to foreign governance authority in a conservative political environment than a liberal political environment.

Realist theories of international relations reinforce the attitudinal and strategic models' emphasis on the political determinants of transnational judicial governance, but with a focus on power rather than ideology. Morgenthau $(1978,5)$ assumes that "statesmen think and act in terms of interest defined as power"; Waltz (1979, 97-98) argues that the distribution of power among states is a fundamental structural variable affecting state behavior; and Mearsheimer $(2001,2)$ posits that "[t]he overriding goal of each state is to maximize its share of world power." Because realist theory generally treats states as unitary actors, it is not clear from a realist perspective how national power should affect transnational judicial governance. ${ }^{14}$ As a general matter, however, one might expect the likelihood of deference by one political actor to another to be greater when the second is more powerful than the first. ${ }^{15}$ This implies the following hypothesis:

Realist Theory Hypothesis (H3): The greater the power of a foreign state, the more likely a judge is to defer to its governance authority.

Nationality is another political factor that may influence transnational judicial governance: domestic courts may be biased in favor of their own nationals (Bhattacharya, Galpin

\footnotetext{
${ }^{14}$ However, as Alter $(2001,40)$ notes, some scholars of European integration argue that the national interest is the primary determinant of judicial decisionmaking. If this is true, then to the extent power defines national interests, it also should influence the decisions of courts.

${ }^{15}$ The opposite may also be a plausible claim, namely that for fear of reinforcing the power of already more powerful states, judges may be less likely to defer to them.
} 
and Haslem 2006; Moore 2003). ${ }^{16}$ This “domestic bias” theory implies the following hypothesis:

Domestic Bias Hypothesis (H4): In a dispute between a domestic party and a foreign party, a judge is more likely to defer to foreign governance authority if the domestic party prefers deference and less likely to do so if the domestic party prefers assertion of domestic governance authority.

Finally, beyond ideology, power and nationality, a fourth potential political factor is regime type. Drawing on the democratic peace literature (Russett and Oneal 2001) and liberal international relations theory (Moravcsik 1997), Anne-Marie Slaughter's liberal theory of international law posits that "the courts of liberal states handle cases involving other liberal states differently from the way they handle cases involving nonliberal states” (Burley 1992, 1917). ${ }^{17}$ Slaughter argues that "the courts of liberal states will be guided [in their legal relations with each other] by general pluralist principles of tolerance and mutual accommodation” (Burley 1992, 1923), which implies that domestic courts in liberal democracies should be more likely to defer to the governance authority of a foreign state when that foreign state also is a liberal democracy. Alvarez (2001, 214-220) disagrees with Slaughter's theory, questioning the tenability of the liberal-illiberal distinction and arguing that the theory simply is not descriptively accurate: the courts of liberal democracies are not necessarily more deferential to the courts of other liberal democracies. To evaluate these competing claims, I will test the following hypothesis:

Liberal Theory Hypothesis (H5): A judge in a liberal democracy is more likely to defer to the governance authority of a foreign state when that foreign state also is a liberal democracy.

\subsection{The Rule of Law in Transnational Judicial Governance}

An alternative conception is that transnational judicial governance is characterized not primarily by politics, but by the rule of law. According to the legal model of judicial decisionmaking, court decisions are based on the application of legal doctrine to the facts of the case. ${ }^{18}$ Unlike the attitudinal and strategic models, which threats judges as policy maximizers, the legal model may be understood as treating judges as "law maximizers": given a particular set of facts, they make the decision that is most consistent with the applicable doctrine of law. For example, Segal (1984) develops a legal model of U.S. Supreme Court decisionmaking in Fourth Amendment search and seizure cases by surveying the Court's search and seizure doctrine to identify a number of specific facts (such as whether the search was of the defendant's home, business, car or person) and subsidiary legal conclusions (such as whether there was probable

\footnotetext{
${ }^{16}$ However, empirical support for this proposition is mixed. While Bhattacharya, Galpin and Haslem (2006) and Moore (2003) find that pro-American bias exists, Clermont and Eisenberg (1996 and 2006) conclude that foreign parties actually fare better than their U.S. counterparts in U.S. federal courts.

${ }^{17}$ She specifically suggests that these differences should be apparent in forum non conveniens decisionmaking (Slaughter Burley 1993, 232), which is the doctrine I explore in the empirical section of this paper.

${ }^{18}$ As characterized by George and Epstein, the legal model posits that "legal doctrine, generated by past cases, is the primary determinant of extant case outcomes” (1992, 324), and, as described by Segal, Songer and Cameron, it holds that judges make decisions based on "the facts of the case in light of [the legal] text, intent, and precedent" (1995, 235).
} 
cause for the search and whether the search was incident to a lawful arrest) that the doctrine identifies as relevant to a determination of whether a search or seizure is reasonable. As Segal clarifies, this type of legal model should not be expected to determine court decisions; but the identified factors "should strongly predispose the Court toward finding the search reasonable or unreasonable” $(1984,893)$ and, in his empirical tests, the model was able to predict accurately a substantial proportion of the Court's decisions. ${ }^{19}$ To derive from the legal model a precise hypothesis about transnational judicial governance, reference must be made to an applicable legal doctrine. However, the legal model does suggest the following general proposition:

Legal Model Hypothesis (H6): When an applicable legal principle states that the existence of a particular fact requires, or militates in favor of, deference to foreign governance authority, a judge is more likely to defer to foreign governance authority when that fact exists than when it does not.

A limitation of the legal model is that it does not explain why legal considerations should have a stronger influence on transnational judicial governance than the political considerations emphasized by other theories of judicial decisionmaking. One possible explanation begins with the observation that the most active courts in transnational judicial governance are trial courts. But the attitudinal model's assumption that judges have wide latitude to reach decisions based on their policy preferences does not hold as well for lower court judges as it does for Supreme Court justices, because the former face a more constraining strategic environment (Segal, Songer, and Cameron 1995, 232), including the possibility that higher courts may overrule them for making legal errors. As Spaeth notes, "[t]hese differences may cause lower-court judges to decide on bases other than their personal policy preferences” (1995, 313).

Moreover, the decisionmaking demands on U.S. district court judges are higher than for Supreme Court justices. The workload of courts is heavy for all levels of the federal judiciary (Carp, Stidham, and Manning 2004, 52); but unlike the Supreme Court, district courts are unable to control their caseload. Since 1995 there have been approximately 400 to 500 pending cases per judge in the U.S. district courts each year. ${ }^{20}$ Because judicial appointments have not kept pace with growing dockets, "federal judges, at both the trial and circuit court levels, are under severe resource and expertise constraints"; they face "an overwhelming caseload and limited time and resources with which to decide those cases” (Bainbridge and Gulati 2002, 86, 102). As a result, "a significant portion of [lower court] decision making must be done on the spur of the moment, without the luxury of lengthy reflection or discussion with staff or colleagues" (Carp, Stidham, and Manning 2004, 282). Given these limitations on their decisionmaking capacity, district court judges ordinarily will not gather information about the preferences and likely decisions of other political actors and make strategic decisions based on analysis of this information, as assumed by the strategic model. Simply put, they are too busy.

The problem is that the combination of heavy caseload and limited resources may also limit the plausibility of the legal model. Legal analysis, like strategic analysis, consumes

\footnotetext{
${ }^{19}$ George and Epstein (1992) used the same approach to develop and empirically test a legal model of Supreme Court decisionmaking in death penalty cases.

${ }^{20}$ The data is from the Federal Court Management Statistics published by the Administrative Office of the U.S. Courts, available at http://www.uscourts.gov/fcmstat/index.html.
} 
substantial decision-making resources. Just as resource constraints make it difficult for judges to engage in the type of decisionmaking process described by the strategic model, these constraints make it difficult for them to engage in the type of decisionmaking process implied by the legal model, including the collection and analysis of legally relevant facts and the systematic application of frequently complex legal principles to those facts.

Therefore, as an alternative to the theories discussed above, I propose a heuristics model of transnational judicial governance that takes into account the limited decisionmaking resources of trial court judges, and posits that U.S. district court decisions are based largely on decisionmaking shortcuts or "heuristics." The theory is premised on three basic assumptions. The neoclassical concept of rationality assumes that individuals maximize their utility by making the choice that yields the greatest expected utility, discounted by costs, based on a comprehensive analysis of available information-which, in the case of uncertainty or incomplete information, includes the estimation of a probability distribution associated with outcomes (Jones 1999, 299). In contrast, following Bainbridge and Gulati (2002) and Segal (1986), I assume that judges are boundedly rational decision makers: that is, they are goaloriented, but due to their cognitive limitations-particularly their limited ability to gather and process information - they are unable to maximize in the neoclassical sense. Because boundedly rational actors cannot maximize, they satisfice: that is, the decisionmaking process is "usually terminated with the discovery of satisfactory, not optimal, courses of action” (Simon 1985, 295). Thus, whereas the legal model treats judges as law maximizers, the heuristics model understands them as "law satisficers."

Second, one way that boundedly rational actors satisfice is by using decisionmaking shortcuts called "heuristics." In the language of cognitive psychology, heuristics involve a process of "attribute substitution": "whenever the aspect of the judgmental object that one intends to judge (the target attribute) is less readily assessed than a related property that yields a plausible answer (the heuristic attribute)," individuals may substitute the former with the latter (Kahneman and Frederick 2005, 269). The relative accessibility of heuristics-in terms of lower information gathering or information processing demands - reduces decisionmaking costs, thus helping decision makers conserve decisionmaking resources. Bainbridge and Gulati (2002), Guthrie, Rachlinksi, and Wistrich (2001) and Segal (1986) have all found that judicial decisionmaking relies heavily on heuristics "to cut down on comprehensive decision making" (Segal 1986, 941), and this makes sense, especially at the district court level where, as discussed above, judges face a particularly acute combination of high decisionmaking demands and limited decisionmaking capacity. ${ }^{21}$ When an applicable legal doctrine specifies the factors for making a particular type of legal decision, these factors can be understood as the relevant target attributes. From this perspective, bounded rationality suggests that if assessing the doctrinally-specified target attributes requires too much information gathering or cognitive effort, judges will replace them with heuristic attributes that are conceptually related and provide plausible answers, but entail lower decision costs. ${ }^{22}$ In plain English, “difficult questions are often answered by

\footnotetext{
${ }^{21}$ As Guthrie, Rachlinski, and Wistrich note, “judges make decisions under uncertain, time-pressured conditions that encourage reliance on cognitive shortcuts” (2001, 783).

${ }^{22}$ For example, Segal noted that more than 100 legal factors are relevant to search and seizure decisionmaking by U.S. Supreme Court justices, but found the justices in fact "monitor a relatively small number of facts from the case, and that the presence or absence of these facts strongly predisposes the justice in his decision” (1986, 942).
} 
substituting an answer to an easier one” (Kahneman and Frederick 2005, 269). More precisely for this study, judges may replace answers to difficult legal questions with answers to related but relatively simple questions.

Third, I assume that the primary operative goal of district court judges is to dispose of the cases on their docket efficiently and in a legally competent manner (Bainbridge and Gulati 2002, 86; Baum 1994, 751). ${ }^{23}$ This assumption has both instrumental and normative foundations. Instrumentally, one goal of judges is to maintain a good professional reputation in the legal community, particularly among other judges (Bainbridge and Gulati 2002, 106-108; Baum 1994, 751-753; Posner 1993, 15). To accomplish this goal, judges must dispose of the cases on their docket without excessive delay and in a legally competent manner. Failure to do so will attract negative attention, damaging a judge's reputation. ${ }^{24}$ In addition, institutional approaches to judicial decisionmaking suggest that one of the norms constituting the institution of judging is the norm of judging in good faith (Gillman 1999, 80; Gillman 2001, 486), ${ }^{25}$ a norm that implies not only good faith legal reasoning but also expeditiousness. ${ }^{26}$ Thus, both a logic of consequences and a logic of appropriateness (March and Olsen 1998) point to the goal of efficient and legally competent disposal of cases. This helps explain why political considerations may not weigh as heavily in transnational judicial governance as implied by other theories.

Given these three assumptions, which heuristics are U.S. district court judges likely to use in transnational judicial governance decisionmaking? Such a heuristic must satisfy two basic conditions. First, it must be easier for judges to use as a basis for decision than the full set of doctrinally-specified factors. That is, the heuristic must reduce decision costs by being more accessible than the target attribute. This requirement is definitional, for an attribute that entails greater decision costs than the target attribute is not a decisionmaking shortcut at all. Moreover, given the goal of judges to dispose of cases efficiently in the face of limited decisionmaking resources and high decisionmaking demands, they have an incentive to use processes that reduce decision costs, but not those that increase decision costs, all else being equal. Second, given the goal of judges to make competent legal decisions, the heuristic must not tend to produce

\footnotetext{
${ }^{23}$ Some attitudinal and strategic modelers may find this assumption difficult to accept. Epstein and Knight (1998, 45) explain that " $[w]$ hile some justices may be motivated to be 'good' justices, we think it is difficult to maintain a proposition suggesting that this idea is in the minds of most [Supreme Court] justices in most cases." However, as Spaeth $(1995,313)$ notes, the situation might be different for lower court judges, and there is evidence that legal influences may be particularly significant at the district court level (Unah 1998, 103). Moreover, as March and Olsen $(1998,952)$ suggest, normative bases for human behavior are likely to be particularly important under conditions of bounded rationality: "When identities and their implications are clear but the implications of preferences or expected consequences are not, a logic of appropriateness tends to be more important." On the distinction between the inherent and operative goals of judges, see Baum (1994, 749-750).

${ }^{24}$ As Murphy, Pritchett and Epstein note, "[f]ew jurists have the temerity (or stupidity) to expose themselves to the scorn of fellow judges, scholars, and journalists by announcing decisions for which they cannot give good, even if controversial, reasons” (2002, 312).

${ }^{25}$ As Kahn explains, "the constitutive approach [to the study of courts] assumes that justices make their decisions in an institutional context which informs the choices that they make" (1999, 175-176).

${ }^{26}$ For example, the Sixth Amendment to the U.S. Constitution gives criminal defendants the right to a "speedy" trial. Thus, to Gillman's description of the norm of good faith judging as "a sense of obligation to make the best decision possible in light of one's general training and sense of professional obligation” (2001, 486), I would add "and in light of one's highly limited decisionmaking resources."
} 
decisions that clearly are legally erroneous. ${ }^{27}$ An implication of this two-fold requirement is that the more closely the heuristic attribute is related to the doctrinally-specified decisionmaking factors, the lower the error costs will be, but the lower the decision costs savings will be as well. In summary, judges are likely to use a heuristic only if it will help them dispose of their cases more quickly and easily than comprehensive decisionmaking based on the doctrinally-specified decisionmaking factors (it must reduce decisionmaking costs), without tending to yield decisions that clearly are legally erroneous under the applicable doctrine (it must not entail excessive error costs) - these are the scope conditions of the heuristic model.

One heuristic for transnational judicial governance decisionmaking that may satisfy these requirements is territoriality. According to the territoriality heuristic, the choice between domestic and foreign governance authority over transnational activity will depend on whether that activity is primarily outside domestic territory. In the language of cognitive psychology, the target attributes of choice between domestic and foreign governance authority-including those factors identified by relatively complex doctrines of private international law-are replaced by the more simple and accessible heuristic attribute of territoriality. ${ }^{28}$ This is not to say that it always is easy for judges to determine the principal locus of transnational activity. ${ }^{29}$ Nevertheless, use of the territorial heuristic is on average likely to entail lower decision costs than the comprehensive application of relevant principles of private international law and, given the relationship of territoriality with many of these principles, the heuristic should not entail excessive error costs. ${ }^{30}$ The extent to which decision costs will be reduced, and the extent to which error costs will be minimized, ultimately cannot be analyzed with precision outside the context of a particular legal doctrine. However, assuming the decision costs and error costs conditions are satisfied, the heuristics model suggests the following hypothesis:

\footnotetext{
${ }^{27}$ More generally, as Kahneman and Frederick note, a heuristic must be a property that is related to the target and "yields a plausible answer" (2005, 269). Some scholars focus on heuristics as a form of conscious adaptation to cognitive constraints, while others focus on them as "unwitting” adaptations (Kahneman and Frederick 2005, 269). As Bainbridge and Gulati note, the former approach is associated with new institutional economics and the latter with behavioral economics (2001, 101-102, n. 60). I do not take a firm position on whether judicial heuristics are primarily conscious or unwitting adaptations, but I do assume that trial court judges will learn through the appellate process about the extent of error costs associated with a heuristic and after reversals are likely to reassess it consciously. Therefore, whether or not heuristics are initially conscious adaptations, I expect that those that are actually used by judges generally will not entail excessive error costs.

${ }^{28}$ Broadly understood, private international law consists of private law, including the law of property, contracts, and torts, as it is applied to transnational activity; as well as the legal principles that guide how domestic courts allocate governance authority. The latter include the three major branches of a subfield of law known in the United States as "conflict of laws": jurisdiction and proper venue, which guides the allocation of adjudicative authority; choice of law, which guides the allocation of prescriptive authority; and enforcement and recognition of judgments, which guides the allocation of enforcement authority (Scoles, Hay, Borchers, and Symeonides 2004, 3).

${ }^{29}$ Determining the locus of transnational activity may be particularly difficult in disputes relating to cyberspace. See, e.g., Berman (2005) and Michaels (2004) (each highlighting the difficulties that cyberspace poses territorial approaches to private international law).

${ }^{30}$ For example, “most significant relationship” analysis under the Second Restatement of Conflict of Laws, the personal jurisdiction and forum inconvenience analysis under the Uniform Foreign Country Money-Judgments Recognition Act and, as discussed below, several elements of forum non conveniens analysis, are all likely to be significantly correlated with the location of the transnational activity. More broadly, territoriality has played an important historical role in private international law (Symeonides, Perdue, and Von Mehren 2003, 296).
} 
Heuristics Model Hypothesis (H7): A judge is more likely to defer to foreign governance authority over transnational activity when that activity is primarily outside domestic territory.

In summary, there is theoretical support both for the proposition that transnational judicial governance is based on politics and for the proposition that it is based on the rule of law. My own intuition, expressed in the heuristics model, takes seriously the insight from institutional approaches to judicial decisionmaking that judges generally abide by a norm of judging in good faith. My model thus provides an explanation for why political factors may not play the important role implied by other theories of judicial decisionmaking and international relations. However, in contrast to the legal model, my model assumes that because of their highly limited decisionmaking resources, judges generally are not able to apply the law systematically to the facts of the case in order to generate decisions - that is, they are unable to behave as "law maximizers." They are more appropriately described as "law satisficers," boundedly rational actors who use heuristics to make decisions efficiently and in a manner that is legally competent. Transnational judicial governance may be based on the rule of law, but it is the rule of law constrained by the reality of limited resources.

\section{4. $\quad$ Research Design: Forum Non Conveniens and Transnational Judicial Governance Decisionmaking in U.S. District Courts}

To empirically test the hypotheses developed above, and to evaluate the descriptive accuracy of the politics and rule-of-law visions of transnational judicial governance, I conducted statistical and qualitative analyses of an original database of over 200 forum non conveniens decisions in U.S. federal district courts. As explained below, forum non conveniens decisionmaking involves an explicit choice between domestic and foreign adjudicative authority over transnational activity, making it an important example of transnational judicial governance.

\subsection{Forum Non Conveniens Doctrine and the Allocation of Adjudicative Authority}

In the context of a particular transnational dispute, the process of allocating adjudicative authority begins with one of the parties to that dispute, the plaintiff, who initially chooses where to initiate the lawsuit. A standard move on the part of defendants in transnational litigation is to seek to have the case removed from the plaintiff's preferred forum. One way to do this is to file a motion asking the judge to dismiss the case on the grounds that it lacks jurisdiction over the defendant or the subject matter of the dispute. However, even if the judge finds that the court does have jurisdiction, another technique is available: the defendant can file a motion asking the judge to dismiss the case in favor of a more appropriate foreign court. The doctrine of forum non conveniens gives U.S. district courts the discretion to grant such motions - that is, to dismiss transnational litigation in favor of a foreign court, thus deferring to foreign adjudicative authority, even if the domestic court has jurisdiction - and it provides the legal principles upon which the court is to base this decision. ${ }^{31}$

\footnotetext{
${ }^{31}$ For detailed discussions of the forum non conveniens doctrine, see Born (1996, chap. 4) and Wright, Miller, and Cooper (2007, 614-746).
} 
A detailed description of the forum non conveniens doctrine is presented in Appendix B. For the purposes of this study, however, the essential point is that the doctrine calls on U.S. district courts to make a choice between the assertion of domestic adjudicative authority and deference to foreign adjudicative authority over transnational activity. As explained in the seminal U.S. Supreme Court case on the doctrine, "[i]n all cases in which the doctrine of forum non conveniens comes into play, it presupposes at least two forums in which the defendant is amenable to process; the doctrine furnishes criteria for choice between them." 32 And this choice matters. As Bermann $(2003,90)$ explains, "With the movement of a case to an internationally different forum are likely to come into play significant and possibly outcome-determinate changes in the applicable procedural or substantive law, including available causes of action, and remedies. Even where two systems have the same textual rules in place, the same result may not obtain due to differences in interpretation of these rules or in the respective courts' characterizations of the facts. Thus, forum non conveniens may prove to be quite a high-stakes game indeed when deployed in the transnational litigation context." 33

Forum non conveniens decisionmaking is an interesting example of transnational judicial governance not only because it involves the allocation of adjudicative authority among states and because choice of forum matters profoundly for transnational actors, but also because it is common. I estimate that U.S. district courts have published at least 691 transnational forum non conveniens decisions between 1990 and 2006, with 95 percent certainty that the actual minimum is between 613 and 775. ${ }^{34}$ Moreover, the rate of forum non conveniens dismissals poses a bit of a theoretical puzzle. The U.S. Supreme Court has made it clear that U.S. district courts ordinarily should respect a plaintiff's choice of forum and that dismissal on forum non

\footnotetext{
${ }^{32}$ Gulf Oil v. Gilbert, 330 U.S. 501 (1947), at 506-507. Although personal jurisdiction raises important issues of transnational judicial governance, forum non conveniens doctrine is particularly well suited for empirically exploring how U.S. federal courts allocate governance authority because, unlike motions to dismiss for lack of personal jurisdiction, court decisions on forum non conveniens motions involve this explicit choice between domestic and foreign adjudicative authority.

${ }^{33}$ Clermont and Eisenberg (1995) find that forum affects outcomes even within the U.S. federal court system: plaintiffs' win rates drop substantially when litigation is transferred from their preferred federal venue to another federal venue. Thus, Clermont $(2004,8)$ argues that " $t]$ he choice of forum has a tremendous impact on the chance of winning and hence on the value of settlement .... The choice of forum becomes much more important [in international litigation]. Shifting inconveniences and changing biases become staggeringly effective. Moreover, the differences in substantive and procedural law — as well as the matters of remedies and expenses-dwarf the small variations within American law." Born $(1996,318)$ notes that "[i]n many cases, the forum non conveniens decision is dispositive, as a practical matter, of the parties' dispute. If the case is dismissed, the plaintiff will effectively capitulate, while the defendant will often settle on generous terms (by international standards) if the case is not dismissed."

${ }^{34}$ By published, I mean cases published either electronically in the Lexis/Nexis Academic database or in official reporters. The total number of cases in the Lexis/Nexis database containing the phrase "forum non conveniens" from 1990 through 2005 was, as of September 28, 2006, 2,791. I analyzed a random sample of 848 of these cases and, after discarding magistrate decisions and purely domestic cases applying the Section 1404(a) federal transfer statute under the misleading label of "forum non conveniens," I identified 210 actual transnational forum non conveniens decisions, resulting in a "success" rate of 24.76 percent (95\% Agresti-Coull confidence interval [.2197487, .2778104]). As discussed above, published decisions are the primary cases of interest from a governance perspective because of their potential to affect the strategic behavior of transnational actors, but it should be noted that these figures may substantially underestimate the total number of forum non conveniens decisions because they do not include unpublished decisions.
} 
conveniens grounds should be rare, ${ }^{35}$ and legal scholars have noted the "high hurdle" facing defendants seeking forum non conveniens dismissals (Bermann 2003, 93). In addition, theories of judicial decisionmaking that treat judges as "policy maximizers" or "jurisdiction maximizers" imply that dismissals should be rare, because by dismissing transnational cases, judges forego opportunities to influence transnational activity. ${ }^{36}$ In contrast to these expectations, I estimate that in 47 percent of published forum non conveniens decisions, U.S. district courts grant the motion, thus dismissing the case in favor of a foreign court, with 95 percent certainty that the actual rate is between 41 and 54 percent (see Table 1 below). One should not, however, attribute too much legal meaning to this estimate without understanding potential selection effects. ${ }^{37}$ Although it is possible that the high dismissal rate indicates unfaithful application of Supreme Court precedents, an alternative explanation might simply be that plaintiffs file a disproportionate number of the transnational cases in U.S. district courts under factual circumstances which genuinely merit dismissal under the doctrine.

\section{Table 1: Forum Non Conveniens Decisions by U.S. District Court Judges, 1990-2005}

\begin{tabular}{lcc}
\hline & Frequency & Percent \\
\hline $\begin{array}{l}\text { Assert Domestic Governance } \\
\text { Authority (Deny Motion) }\end{array}$ & 111 & 52.86 \\
$\begin{array}{l}\text { Defer to Foreign Governance } \\
\text { Authority (Grant Motion) }\end{array}$ & 99 & 47.14 \\
\hline Total & 210 & 100.00
\end{tabular}

Note: Agresti-Coull 95\% Confidence Interval for Foreign Court: 40.5 to 53.9 percent.

Finally, the forum non conveniens doctrine provides an appropriate domain for testing the heuristics model hypothesis because the territorial heuristic would appear to satisfy both the decision costs and error costs conditions. ${ }^{38}$ Forum non conveniens is a fairly complex legal

\footnotetext{
${ }^{35}$ In Gulf Oil Corp. v. Gilbert, the U.S. Supreme Court emphasized that "unless the balance is strongly in favor of the defendant, the plaintiff's choice of forum should rarely be disturbed.” 330 U.S. 501, at 508 (1947).

${ }^{36}$ In addition to the attitudinal and strategic models discussed above, Alter (2001, 45-46) argues that "[j]udges are primarily interested in promoting their independence, influence, and authority. ... By influence, I mean that courts want to promote their ability to make decisions that can influence the policy process and the judicial process. ... By authority, I mean that judges protect their legal turf (their jurisdiction) and the finality of their decisions.”

${ }^{37}$ For a discussion of the difficulties that selection effects pose for the interpretation of win rates in litigation, see Clermont and Eisenberg (2002).

${ }^{38}$ As Geddes $(2003,96)$ explains, "[t]he appropriate universe of observations on which to test a hypothesis depends on the domain implied by the hypothesis." The domain of the heuristics model hypothesis is restricted to settings in which the decision costs and error costs conditions are satisfied. Forum non conveniens is one such setting. Testing the heuristics model hypothesis in such a setting does not pose a selection bias problem, because there is no a priori theoretical reason to expect heuristics to have an impact outside this domain. Indeed, testing the hypothesis outside its domain would create a different threat to inference, namely the risk of violating the assumption of causal homogeneity (Collier, Mahoney, and Seawright 2004, 88). Of course, one must use caution extending this study's findings about heuristics in forum non conveniens decisionmaking to judicial decisionmaking in general, and without further empirical analysis, even extending the inferences to other examples of judicial decisionmaking within the theory's domain must be done carefully.
} 
doctrine, the thorough application of which requires a judge not only to determine the availability and adequacy of the alternative forum proposed by the defendant, but also to consider and balance a range of private and public interest factors (see Appendix B). In contrast, the territorial heuristic requires only that the judge reach a conclusion about whether the underlying transnational activity occurred mostly or entirely outside U.S. territory. By replacing the target attributes identified by the forum non conveniens doctrine with the relatively simple and accessible heuristic attribute of territoriality, judges should be able to reduce the decisionmaking costs of choosing between domestic and foreign adjudicative authority.

Regarding error costs, the forum non conveniens doctrine does not refer to the locus of the transnational activity that gives rise to a dispute. However, the locus of transnational activity generally should be significantly correlated with several factors that are included in the doctrine. For example, ease of access to evidence, which is emphasized by the doctrine's private interest factors, depends on the location of relevant documents and witnesses, which in turn will often overlap with the place of the activity giving rise to the dispute. In addition, one of the public interest factors is whether the underlying dispute is a "localized controversy." The meaning of the phrase is not defined, but it implies that one of the parties or some part of the underlying activity is local. Therefore, substituting the territoriality heuristic for the target attributes identified in the forum non conveniens doctrine should not entail excessive error costs, allowing judges to make decisions that, in light of their resource constraints, are satisfactory from the perspective of good faith judging.

\subsection{Sample and Dependent Variable}

My hypothesis tests are based on analysis of a random sample of more than 200 published forum non conveniens decisions made between 1990 and 2005. ${ }^{39}$ My dependent variable, "Deference to Foreign Governance Authority," indicates whether the court decided to assert domestic adjudicative authority by denying the defendant's forum non conveniens motion and keeping the case (0), or defer to foreign adjudicative authority by granting the motion and dismissing the case in favor of a foreign court (1). The independent variables are explained below, and summary statistics are reported in Appendix A.

\footnotetext{
${ }^{39}$ My sample of forum non conveniens decisions was generated in three steps. First, I searched the LexisNexis Academic database of U.S. district court decisions for the term "forum non conveniens." I then randomly sorted them. Finally, I analyzed each case in the randomly generated order, discarding those that were not actual decisions by U.S. district court judges to either grant or deny a motion to dismiss in favor of a foreign court on forum non conveniens grounds, until I had a sample of approximately 200 observations. This screening approach follows Koremenos' approach to generating a random sample of international agreements (2005, 554). The exact number of observations in my dataset is 210. To obtain this number, I had to screen 848 cases out of a total of 2,791 hits for the search term "forum non conveniens." Thus, I estimate that there are a total of 691 actual forum non conveniens decisions in the LexisNexis database between 1990 and 2005, with my dataset constituting 30\% of those decisions. Discarded cases included those deciding motions to transfer from one U.S. district court to another under Section 1406(a) of Title 28 of the United States Code rather than to dismiss in favor of a foreign court; decisions made by magistrate judges rather than district court judges (except in two cases where the magistrate was authorized to make the final order); and those in which a forum non conveniens issue was discussed, but no forum non conveniens motion was granted or denied. Decisions granting motions to dismiss on alternative grounds including forum non conveniens were included in the dataset.
} 


\subsection{Independent Variables}

To test the attitudinal model hypothesis (H1), I used the variable "Republican Judge," which indicates whether the judge's party affiliation is Republican ( 0 if no, 1 if yes). ${ }^{40}$ To test the strategic model hypothesis (H2), I used the variable "Republican Environment," which indicates whether, in the year of the court's decision, the political environment is Republican (0 if no, 1 if yes). I coded the political environment as Republican if the president and at least one house of Congress were Republican, and as not Republican if the president was Democratic or both houses of Congress were Democratic. ${ }^{41}$ For the realist theory hypothesis (H3), I used the foreign state's annual gross domestic product ("Foreign State's GDP”) and its total annual military spending ("Foreign State’s Military Spending"). ${ }^{42}$ To test the domestic bias hypothesis (H4), I used two dummy variables, one indicating whether there is a plaintiff that is a U.S. citizen ("Domestic Plaintiff," 0 if no, 1 if yes), and the other indicating whether there is a defendant that is a U.S. citizen ("Domestic Defendant," 0 if no, 1 if yes). ${ }^{43}$ Because a forum non conveniens motion is an attempt by the defendant to thwart the plaintiff's choice of forum, one would expect the presence of a U.S. plaintiff to decrease the likelihood of dismissal and the presence of a U.S. defendant to increase the likelihood of dismissal. To test the liberal theory hypothesis (H5), I used the variable "Liberal Democracy," which indicates whether the foreign state was rated "Free" by the Freedom House Freedom in the World Survey for the year prior to the court's decision ( 0 if no, 1 if yes). ${ }^{44}$

\footnotetext{
${ }^{40}$ The use of party affiliation as a measure for a judge's ideology follows George and Epstein $(1992,328)$ and George (1998, 1651-1652). To create the variable, I began by using the political party of the nominating president as a proxy for the judge's political party, again following George and Epstein $(1992,328)$ and George $(1998,1651$ 1652), using data from the Federal Judicial Center's Biographical Directory of Federal Judges available at http://www.fjc.gov/public/home.nsf/hisj. I then made corrections when Martinek's (2005) Lower Federal Court Confirmation Database contained data on a judge's personal partisan identification that was different from that of the nominating president, which was the case for 18 observations in my dataset.

${ }^{41}$ This approach is based on George and Epstein's $(1992,328)$ method of measuring the political environment, although I use a dummy variable rather than their three-level measure to ensure adequate cell size for the logit analysis. For simplification and to account for lame-duck status, I did not account for January when coding presidential transition years. For the Senate, I coded 2001 and 2002 as Democratic, because Democrats were in the majority for 8 of 12 months in 2001 and 11 of 12 months in 2002.

${ }^{42}$ This approach follows Guzman and Simmons (2005). I use data for the year 2000 and apply a natural logarithmic transformation to improve symmetry. The data source is the World Bank's World Development Indicators, available at http://devdata.worldbank.org/data-query/. I only report results using Foreign State's GDP because Foreign State's Military Spending was not statistically significant in any of my tests, it has more missing data than Foreign State's GDP and, except as otherwise noted below, using it instead of Foreign State's GDP as a measure of power did not change the level of statistical significance of any other variables included in my models.

${ }^{43}$ I coded these variables based on the citizenship of the plaintiffs indicated in the court's opinion or, in the absence of citizenship information, based on residence or jurisdiction of incorporation. I counted only parties that joined in or opposed the forum non conveniens motion.

${ }^{44}$ Although these ratings generally are stable over time during the period covered by my dataset, I use a one-year lag on the theory that a boundedly rational judge is unlikely to become immediately aware of even substantial changes in a foreign state's politics. For purposes of her theory, Slaughter defines "liberal" states as those "with juridical equality, constitutional protections of individual rights, representative republican governments, and market economies based on private property rights” (Burley 1992, 1909). The Freedom House rankings capture these characteristics quite nicely, by explicitly accounting for equal treatment under the law, protection of individual rights (including freedoms of assembly, open public discussion, and defendants' rights), representative government (including election of representatives through free and fair elections and other political rights), and private property rights (Freedom House 2006). The other leading measure of democracy, Polity IV, captures the concept of
} 
As Appendix B explains, of the three main elements of the forum non conveniens doctrine - the level of deference owed to plaintiff's choice of a U.S. court, the availability and adequacy of the foreign court proposed by the defendant, and the balance of private and public interest factors - only the first provides a basis for deriving a statistical test of the legal model hypothesis (H6). As the Supreme Court stated in Piper v. Reyno (1981), "a plaintiff's choice of forum is entitled to greater deference when the plaintiff has chosen the home forum. When the home forum has been chosen, it is reasonable to assume that this choice is convenient. When the plaintiff is foreign, however, this assumption is much less reasonable. Because the central purpose of any forum non conveniens inquiry is to ensure that the trial is convenient, a foreign plaintiff's choice deserves less deference." 45 Thus, the citizenship of the plaintiff is a specific doctrinally-relevant fact which should, according to the legal model, influence the choice between domestic and foreign adjudicative authority in the forum non conveniens context. To test this hypothesis, I use the Domestic Plaintiff and Domestic Defendant dummy variables described above. If the doctrinal bias in favor of U.S. plaintiffs is influencing the choice between domestic and foreign adjudicative authority, then the plaintiff's nationality variable should have an effect. However, if there is a general bias in favor of U.S. parties that goes beyond that permitted by doctrine, as implied by the domestic bias hypothesis (H4), then both dummy variables should have an effect.

I used two alternative variables to test the heuristics model hypothesis (H7). First, I used the "Territoriality (Place)" variable, which indicates whether the place of the activity giving rise to the transnational litigation was all or mostly outside U.S. territory ( 0 if no, 1 if yes). I coded the variable based on two factors, the place of the conduct of the defendant complained of by the plaintiff, and the place of the plaintiff's alleged injury, each as stated in the court's opinion. I coded the place variable as "yes" if both the place of conduct and the place of injury were entirely foreign, if the place of conduct was entirely foreign and the place of injury mixed, or if the place of injury was entirely foreign and the place of conduct mixed. When the place of conduct and place of injury were both mixed or all or mostly inside U.S. territory, I coded the place variable as "no," because under these circumstances the territoriality heuristic is not expected to point toward dismissing the case in favor of a foreign court.

As an alternative measure, I used the "Territoriality (Contacts)" variable, which I based on a count of the number of statements in the court's opinion referring to actions or things located inside U.S. territory and outside U.S. territory. The variable equals the percentage of these contacts that are foreign. This measure counts only statements about the activity giving rise to the transnational litigation. For two reasons, it excludes statements about the location of evidence and witnesses and the location of the parties during the litigation. First, because the theoretical concept of interest is the locus of the activity giving rise to the parties' dispute, including these statements would result in measurement error. Second, because these statements are directly related to the private interest factors enumerated in the forum non conveniens doctrine, including them would make it difficult for the variable to distinguish heuristic effects from legal effects.

representative government well, but only indirectly captures the other elements of Slaughter's definition. Therefore, for testing Slaughter's liberal theory of international law, the Freedom House measure is more appropriate.

454 U.S. 235, 266. 
I control for two additional variables for which there are theoretical grounds to expect an influence on judicial decisionmaking in this context. First, recent scholarship on the U.S. Supreme Court and the U.S. courts of appeals has identified case salience as a factor influencing judicial decisionmaking (Hettinger, Lindquist, and Martinek 2004; Unah and Hancock 2006). As Hettinger, Lindquist and Martinek $(2004,130)$ argue in their study of dissenting behavior by appellate court judges, "the more salient a case is, the more likely it is to have policy consequences and, hence, the more likely it is to stimulate judges to devote the necessary effort to write a dissenting opinion.” This reasoning implies that judges also should be less likely to grant motions to dismiss on forum non conveniens grounds in cases that raise particularly salient legal issues. To control for salience, I used two variables. "Federal Statute" indicates whether the dispute involved an issue under a U.S. federal statute (0 if no, 1 if yes), on the theory that U.S. district court judges are likely to find such issues more important than state common law and state statutory issues such as those common in ordinary personal injury and commercial litigation. "Political" indicates whether the dispute involved human rights or other politically salient transnational issues ( 0 if no, 1 if yes). ${ }^{46}$

Caseload may also have an influence on lower court judicial decisionmaking, although the evidence is mixed (Hettinger, Lindquist, and Martinek 2004, 134). In the case of forum non conveniens decisionmaking, the implication would be that busier U.S. district courts are more likely to dismiss litigation in favor of a foreign court because this allows them to reduce their caseload. In fact, by including “[a]dministrative difficulties” resulting from congestion in its list of public interest factors, the Supreme Court in Gilbert v. Gulf Oil (1947) can even be understood as acknowledging that the forum non conveniens doctrine may be used as a caseload management tool. To control for caseload effects, I used the variable "Caseload," which measures the number of cases filed in each district in the year prior to the court's decision. ${ }^{47}$

\section{Results and Discussion}

\subsection{Politics or Rule of Law? A Statistical Analysis}

To empirically assess the influence of the political and rule-of-law factors discussed above on the choice between domestic and foreign adjudicative authority in forum non conveniens decisionmaking, I conducted a series of logit analyses, the results of which are presented in Table 2 below.

\footnotetext{
${ }^{46}$ I coded these variables based on the description of the legal issues in the court's opinion. Because Political equals 1 in only nineteen cases, some of the cells in the cross-tabulation of Political and my dependent variable may be insufficiently populated for logit analysis to be reliable (e.g. only 5 observations with Deference to Foreign Authority= 1 and Political=1 and only 14 observations with Deference to Foreign Authority=0 and Political=1). Therefore, my logit table only reports results using the Federal Statute measure of salience. Except as otherwise noted, Political was not statistically significant and using it instead of Federal Statute did not change the level of statistical significance of other variables in my models.

${ }^{47}$ I use the natural logarithm of the “weighted filings per judgeship” figure from the Federal Judicial Center's Federal Court Management Statistics, Judicial Caseload Profiles, available at http://www.uscourts.gov/fcmstat/index.html, in the year prior to the court's decision. I use a one-year lag on the theory that because of the duration of cases, the prior year's filings are likely to be a more accurate measure of the district's current workload. I applied the logarithmic transformation to increase symmetry.
} 


\begin{tabular}{|c|c|c|c|c|}
\hline Independent Variable & $\begin{array}{l}\text { Model } 1 \\
\text { (Politics) }\end{array}$ & $\begin{array}{c}\text { Model } 2 \\
\text { (Rule of Law) }\end{array}$ & $\begin{array}{c}\text { Model } 3 \\
\text { (Full Model) }\end{array}$ & $\begin{array}{c}\text { Model } 4 \\
\text { (Full Model) }\end{array}$ \\
\hline Republican Judge & $\begin{array}{l}-0.477 \\
(0.333) \\
{[0.152]}\end{array}$ & & $\begin{array}{l}-0.531 \\
(0.365) \\
{[0.146]}\end{array}$ & $\begin{array}{l}-0.519 \\
(0.363) \\
{[0.152]}\end{array}$ \\
\hline Republican Environment & $\begin{array}{l}-0.686 \\
(0.361) \\
{[0.057]}\end{array}$ & & $\begin{array}{l}-0.633 \\
(0.394) \\
{[0.108]}\end{array}$ & $\begin{array}{l}-0.562 \\
(0.398) \\
{[0.157]}\end{array}$ \\
\hline Domestic Plaintiff & $\begin{array}{c}-1.826^{* * *} \\
(0.385) \\
{[0.000]}\end{array}$ & $\begin{array}{c}-1.017 * * \\
(0.330) \\
{[0.002]}\end{array}$ & $\begin{array}{c}-1.435^{* * *} \\
(0.415) \\
{[0.001]}\end{array}$ & $\begin{array}{c}-1.765^{* * *} \\
(0.416) \\
{[0.000]}\end{array}$ \\
\hline Domestic Defendant & $\begin{array}{l}-0.394 \\
(0.370) \\
{[0.287]}\end{array}$ & & $\begin{array}{l}-0.480 \\
(0.403) \\
{[0.233]}\end{array}$ & $\begin{array}{l}-0.335 \\
(0.403) \\
{[0.406]}\end{array}$ \\
\hline Foreign State's GDP (log) & $\begin{array}{l}-0.082 \\
(0.097) \\
{[0.400]}\end{array}$ & & $\begin{array}{c}0.025 \\
(0.106) \\
{[0.811]}\end{array}$ & $\begin{array}{l}-0.015 \\
(0.107) \\
{[0.891]}\end{array}$ \\
\hline Liberal Democracy & $\begin{array}{l}1.262^{* *} \\
(0.438) \\
{[0.004]}\end{array}$ & & $\begin{array}{l}1.432 * * \\
(0.465) \\
{[0.002]}\end{array}$ & $\begin{array}{l}1.348^{* *} \\
(0.472) \\
{[0.004]}\end{array}$ \\
\hline Territoriality (Place) & & $\begin{array}{c}1.586 * * * \\
(0.337) \\
{[0.000]}\end{array}$ & $\begin{array}{c}1.861 * * * \\
(0.395) \\
{[0.000]}\end{array}$ & \\
\hline Territoriality (Contacts) & & & & $\begin{array}{c}4.270 * * * \\
(0.900) \\
{[0.000]}\end{array}$ \\
\hline Federal Statute & $\begin{array}{l}-0.187 \\
(0.356) \\
{[0.600]}\end{array}$ & $\begin{array}{l}-0.547 \\
(0.354) \\
{[0.122]}\end{array}$ & $\begin{array}{l}-0.442 \\
(0.399) \\
{[0.268]}\end{array}$ & $\begin{array}{l}-0.391 \\
(0.387) \\
{[0.312]}\end{array}$ \\
\hline Caseload (log) & $\begin{array}{c}0.279 \\
(0.668) \\
{[0.676]}\end{array}$ & $\begin{array}{l}-0.121 \\
(0.630) \\
{[0.847]}\end{array}$ & $\begin{array}{l}0.068 \\
(0.713) \\
{[0.924]}\end{array}$ & $\begin{array}{l}0.216 \\
(0.722) \\
{[0.765]}\end{array}$ \\
\hline Constant & $\begin{array}{l}-0.010 \\
(4.244) \\
{[0.998]}\end{array}$ & $\begin{array}{c}0.445 \\
(3.863) \\
{[0.908]}\end{array}$ & $\begin{array}{l}-1.243 \\
(4.503) \\
{[0.782]}\end{array}$ & $\begin{array}{l}-3.139 \\
(4.653) \\
{[0.500]}\end{array}$ \\
\hline $\begin{array}{l}\text { Number of Observations } \\
\text { LR Chi2 } \\
\text { Prob.>LR Chi2 }\end{array}$ & $\begin{array}{c}193 \\
37.025 \\
0.000\end{array}$ & $\begin{array}{c}203 \\
46.826 \\
0.000\end{array}$ & $\begin{array}{c}191 \\
63.103 \\
0.000\end{array}$ & $\begin{array}{c}193 \\
65.709 \\
0.000\end{array}$ \\
\hline
\end{tabular}

Model 1 is a "political” model of transnational judicial governance, including variables measuring the judge's ideology, the political environment, the nationality of the parties, the foreign state's power, and the foreign state's democracy rating, along with control variables for salience and caseload. The results are mixed. On the one hand, they support the liberal theory hypothesis (H5): the positive sign of the coefficient for Liberal Democracy indicates that the probability of deference to foreign adjudicative authority is higher when the foreign state is a 
liberal democracy, and the effect is statistically significant at a 99 percent confidence level. ${ }^{48}$ In addition, the negative sign of the coefficient for Republican Environment suggests that a Republican political environment may decrease the probability of deference, but because this effect is only significant at a 90 percent confidence level, this provides only mild support for the strategic model hypothesis (H2). ${ }^{49}$ On the other hand, and contrary to the attitudinal model hypothesis (H1) and the realist theory hypothesis (H3), neither the judge's political party nor the foreign state's economic power has a statistically significant effect on the probability of deference to foreign adjudicative authority. The results also suggest that contrary to the domestic bias hypothesis (H4), there is no general bias in U.S. federal courts toward domestic parties in forum non conveniens decisionmaking. While the presence of a domestic plaintiff decreases the likelihood of deference to foreign adjudicative authority, the nationality of the defendant does not have a statistically significant effect.

Model 2 is a "rule of law" model of transnational judicial governance. It includes the Domestic Plaintiff variable indicating the nationality of the plaintiff which, as discussed above, is a factor that the forum non conveniens doctrine explicitly indicates should have a bearing on the choice between domestic and foreign adjudicative authority. It also includes the Territoriality (Place) measuring the locus of transnational activity which, according to my heuristics model hypothesis (H7), is a heuristic that judges use to choose between domestic and foreign governance authority in a manner that reduces decision costs but nevertheless is legally competent. Like Model 1, Model 2 includes the salience and caseload controls. Consistent with the legal model hypothesis (H6), the presence of a domestic plaintiff reduces the probability of deference to foreign adjudicative authority, and this effect is statistically significant at a 99 percent level of confidence. The results also provide strong support for the heuristics model hypothesis (H7): the positive coefficient for the Territoriality (Place) variable indicates that the probability of deference is higher when the transnational activity occurred primarily outside U.S. territory, and the effect is significant above the 99 percent level of confidence.

Model 3 combines the political and rule-of-law factors. The results suggest that among the political factors, only democracy has a statistically significant effect on the choice between domestic and foreign adjudicative authority, while both of the rule-of-law factors-the plaintiff's nationality and the place of the transnational activity - have their hypothesized effects and are highly statistically significant. The Federal Statute variable, which I use to control for salience, is not statistically significant. Nor is the Caseload control variable, which suggests that U.S. district courts do not use forum non conveniens decisionmaking as a docket management tool. These basic results do not change when Territoriality (Place) is replaced by Territoriality

\footnotetext{
${ }^{48}$ That is, the p-value indicates that there is less than a 1 percent (.01) probability that the apparent relationship between the explanatory and dependent variable is a result of Type I error (i.e., that the null hypothesis-that there is no relationship between the explanatory and dependent variable-is true, and the relationship suggested by the coefficient simply is a result of chance). Political scientists generally do not consider an effect to be statistically significant if the p-value is greater than .05 (i.e. if there is more than a 5 percent likelihood of Type I error).

${ }^{49}$ Republican Environment becomes statistically significant at a 95\% confidence level when the foreign state's power is measured by Foreign State' Military Spending rather than Foreign State's GDP in the political model, but this does not occur when the same substitution is made in the full model (Models 3 and 4).
} 
(Contacts). ${ }^{50}$ Thus, the choice between domestic and foreign governance authority appears to be based on a combination of a political factor - whether the foreign state is a liberal democracyand rule-of-law factors, including the plaintiff's nationality and the territoriality heuristic.

But which factors are substantively most important? Table 3 provides estimates of the impact that a change in each statistically significant independent variable has on the probability of deference to foreign adjudicative authority in forum non conveniens decisionmaking, and for each estimate it also provides the 95 percent confidence interval. ${ }^{51}$ U.S. district courts are an estimated 32 percent more likely to defer to the adjudicative authority of foreign states that are liberal democracies than those that are not, with 95 percent certainty that the actual increase in probability is between 10 and 52 percent. They are an estimated 21 percent less likely to defer to foreign adjudicative authority when a plaintiff is a U.S. citizen, with 95 percent certainty that the actual decrease is between 9 and 36 percent. The strongest substantive impact is from the place of the transnational activity: U.S. district courts are an estimated 42 percent more likely to defer to foreign adjudicative authority when the underlying transnational activity occurred all or mostly outside U.S. territory, with 95 percent certainty that the actual increase is between 25 and 56 percent.

\section{Table 3. Simulated Effects of Independent Variable Changes on Probability of Deference to Foreign Adjudicative Authority}

\begin{tabular}{lccc}
\hline Independent Variable & Value Change & $\begin{array}{c}\text { Probability } \\
\text { Change }\end{array}$ & $\begin{array}{c}95 \% \text { Confidence } \\
\text { Interval }\end{array}$ \\
\hline Liberal Democracy & no $\rightarrow$ yes & .322 & {$[.103, .515]$} \\
Domestic Plaintiff & no $\rightarrow$ yes & -.205 & {$\left[\begin{array}{ll}-.359, & -.092\end{array}\right]$} \\
Territoriality (Place) & no $\rightarrow$ yes & .421 & {$[.251, .564]$}
\end{tabular}

Notes: For each change in a variable's value, all other variables are held constant at their modes if they are dummy variables and at their means if they are continuous variables.

Moreover, the rule-of-law model overall appears to do a better job predicting actual decisions than the politics model. Table 4 compares various measures of fit for Model 1 (Politics) and Model 2 (Rule of Law), with observations with missing data dropped to ensure that the tests are run on the same samples. The rule-of-law model correctly classifies the choice between domestic and foreign adjudicative authority approximately 6 percent more often than the politics model, and the adjusted count $\mathrm{R}^{2}$ figures indicate that the rule-of-law model contributes 12 percent more accuracy beyond simply predicting the more frequent outcome than

\footnotetext{
${ }^{50}$ However, the Political variable is statistically significant and has the anticipated negative sign when it is used instead of Federal Statute with Territoriality (Contacts) in the full model (Model 4). I take this as an indication that the salience hypothesis merits further testing.

${ }^{51}$ I used the Clarify software program (Tomz, Wittenberg, and King 2001) to simulate a change in the expected value of the dependent variable caused by increasing each independent variable from 0 to 1 (in the case of dummy variables) and from the $25^{\text {th }}$ to the $75^{\text {th }}$ percentile (in the case of continuous variables), setting each of the other variables at their mode (for dummy variables) or mean (for continuous variables), and based on Model 3.
} 
the politics model contributes. The area under the ROC curves for the two models suggest that the rule-of-law model may be slightly more discriminating, and the results also provide very strong evidence that the rule-of-law model is preferable according to the Bayesian information criterion. Although the measures of fit presented in Table 4 provide only rules of thumb for comparing statistical models, they all suggest that rule-of-law factors may be playing a more important role than political factors in the choice between domestic and foreign adjudicative authority.

\begin{tabular}{|c|c|c|c|}
\hline & $\begin{array}{c}\text { Model } 1 \\
\text { Politics }\end{array}$ & $\begin{array}{c}\text { Model } 2 \\
\text { Rule of Law }\end{array}$ & Difference \\
\hline Correctly Classified & .655 & .712 & .057 \\
\hline Adjusted Count $\mathrm{R}^{2}$ & .283 & .402 & .120 \\
\hline Area under ROC Curve & .743 & .757 & .014 \\
\hline $\begin{array}{l}\text { Bayesian Information } \\
\text { Criterion }\end{array}$ & -739.960 & -767.119 & -27.159 \\
\hline \multicolumn{4}{|c|}{$\begin{array}{l}\text { Notes: The correctly classified figure indicates the proportion of outcomes that were correctly classified by the } \\
\text { model using a } .5 \text { probability cutoff to translate predicted probabilities into dichotomous predictions (Hamilton } 2004 \text {, } \\
270-271 \text { ). Thus, it indicates the proportion of outcomes for which the model estimated at least a .5 probability of } \\
\text { deference to foreign governance authority, and the court in fact defers. Adjusted count } \mathrm{R}^{2} \text { is the proportion of } \\
\text { correct predictions beyond the number that would be correctly predicted simply by choosing the outcome with the } \\
\text { largest percentage of observed cases, using a .5 probability cutoff (Long and Freese } 2006,111-112 \text { ). The ROC } \\
\text { curve plots } 1 \text { minus the specificity (the false positive rate) on the x-axis and sensitivity (the true positive rate) on the } \\
\text { y-axis for each possible probability cutoff. The area under the ROC curve is equal to the probability that a random } \\
\text { decision granting a forum non conveniens motion has a higher value of the dependent variable than a random } \\
\text { decision denying a forum non conveniens motion (Altman and Bland 1994, 188). The larger the area under the } \\
\text { curve, the more discriminating the model. The BIC is the Bayesian information criterion. The more negative the } \\
\text { BIC, the better the fit, and the greater the absolute difference between the BIC of two models, the stronger the } \\
\text { evidence that one is to be preferred over the other. As a rule of thumb, an absolute difference of } 0-2 \text { is considered } \\
\text { weak, 2-6 positive, } 6-10 \text { strong, and greater than } 10 \text { very strong evidence (Long and Freese } 2006,112-113 \text { ). }\end{array}$} \\
\hline
\end{tabular}

\subsection{Law or Heuristics? A Qualitative Analysis}

My logit analysis provides evidence indicating that both the pro-domestic plaintiff bias of the forum non conveniens doctrine and the territoriality heuristic influence the choice between domestic and foreign adjudicative authority. But is law or heuristics more important in forum non conveniens decisionmaking? I have argued that because U.S. district court judges face a combination of high decisionmaking demands and limited decisionmaking resources, the heuristics model is more convincing theoretically. Empirically, however, the logit analysis does not clearly indicate whether the heuristics model or the legal model describes the more important causal mechanism. As discussed above, a change from "no" to "yes" in the Territoriality (Place) variable has a substantively larger impact on the probability of dismissal (42 percent) than the 
same change in the Domestic Plaintiff variable (-21 percent). In addition, the Territoriality (Place) variable alone more accurately classifies outcomes than that the Domestic Plaintiff variable alone. $^{52}$ These quantitative indictors suggest that heuristics may play a more important role than legal doctrine in the choice between domestic and foreign adjudicative authority.

However, as Baum (1994, 762) points out, in judicial decisionmaking “a particular pattern of behavior usually is susceptible to more than one reasonable interpretation.” This problem cannot be taken lightly in the study of judicial heuristics. For a particular heuristic to be a plausible explanation for judicial decisionmaking, it must tend not to result in decisions that clearly are legally erroneous, which means that it must have some relationship to doctrinallyspecified decisionmaking factors. But this creates a risk that a pattern of decisionmaking that appears driven by such a heuristic may in fact partly reflect legal analysis of those factors rather than the use of decisionmaking shortcuts. To mitigate this risk and to discriminate more effectively between law and heuristics, I conducted a qualitative analysis of each of the 210 judicial opinions in my dataset using the method of structured, focused comparison (George and Bennett 2005, chap. 3). The comparison focuses on the judge's legal analysis of the forum non conveniens issue as set forth in the opinion, with the goal of evaluating the extent to which the judge actually analyzed the factors specified in the U.S. Supreme Court's statement of the forum non conveniens doctrine. An observable implication of the legal model is that most of these factors will be analyzed, whereas an observable implication of the heuristics model is that at least some of them will not. ${ }^{53}$ To structure the comparison, I divided the forum non conveniens doctrine, as set forth in by the Supreme Court in Gilbert v. Gulf Oil and Piper v. Reyno, into eleven distinct elements (see the table in Appendix B), and systematically applied them by giving each case one point for each element of doctrine analyzed in the opinion. ${ }^{54}$

Table 5 below presents the results of the qualitative analysis. Overall, U.S. district court judges include in their opinions an average of only five of eleven elements of forum non conveniens analysis. This represents an estimated average of 48 percent of the elements, with a 95 percent level of confidence that the actual average is between 44 and 52 percent. The result is consistent across the four main parts of the forum non conveniens doctrine, with only 47 percent of cases addressing the level of deference owed to the plaintiff's choice of forum based on the plaintiff's citizenship, and only 55 percent including an analysis of the proposed alternative forum. ${ }^{55}$ Similarly, judges analyzed an average of only 2.15 private interest elements out of four and only 2.11 public interest elements out of five. This evidence is what the heuristics model would predict, but it is difficult to reconcile with the legal model. Therefore, although the logit

\footnotetext{
${ }^{52}$ The principal measures of fit all favor Territoriality (Place) over Domestic Plaintiff (proportion correctly classified .698 versus .668; adjusted count $\mathrm{R}^{2}$ of .347 versus .284, area under ROC curve of .700 versus .669 , and BIC of -831.280 versus -821.143 ), with observations with missing data dropped to ensure that the tests are run on the same samples.

${ }^{53}$ As Segal $(1984,894)$ and Spaeth $(1995,296)$ note, the presence of analysis in a judicial opinion does not necessarily mean that it was an a priori basis for the judge's decision rather than a post hoc justification for it. Thus, there is some risk that my method overestimates the impact of legal analysis.

${ }^{54}$ Legal analysis is the application of applicable legal principles to the facts in order to generate a legal conclusion. Therefore, I gave points for combined statements of law and fact, but not for mere recitation of legal principles or summary legal conclusions not explicitly based on some fact.

${ }^{55}$ Note that in some cases the judge may omit analysis of the alternative forum because the plaintiff does not challenge its availability and adequacy.
} 
analysis above suggests that at least one legal factor-whether the plaintiff is domestic — has an important influence on forum non conveniens decisionmaking, I tentatively conclude that the heuristics model more accurately describes the causal mechanism that underlies the choice between domestic and foreign adjudicative authority. This form of transnational judicial governance indeed appears largely based on the rule of law—not the "law maximizing" idealtype rule of law implied by the legal model, but rather the "law satisficing" rule of law implied by the heuristics model.

\begin{tabular}{|lcccc|}
\hline \multicolumn{5}{l}{ Table 5. Elements of Forum Non Conveniens Analysis Included in Judges' Opinions } \\
\hline $\begin{array}{l}\text { Elements of Forum Non } \\
\text { Conveniens Analysis }\end{array}$ & $\begin{array}{c}\text { Points } \\
\text { Possible }\end{array}$ & Mean & Std. Error & $\begin{array}{c}\text { 95\% Confidence } \\
\text { Interval }\end{array}$ \\
\hline Level of Deference & 1 & .467 & .034 & {$[.400, .534]$} \\
Alternative Forum & 1 & .552 & .034 & {$[.485, .618]$} \\
Private Interest Factors & 4 & 2.152 & .081 & {$[1.993,2.311]$} \\
Public Interest Factors & 5 & 2.110 & .108 & {$[1.900,2.323]$} \\
\hline Total & 11 & 5.281 & .206 & {$[4.875,5.687]$} \\
\hline
\end{tabular}

\subsection{Threats to Causal Inferences: Judicial Fact Discretion and Selection Bias}

Like all research designs, mine involves tradeoffs that may pose threats to the causal inferences I have made. First, my measures of territoriality are based on statements contained in court opinions. The potential problem is that to the extent judges selectively report the facts of a case as part of a post hoc legal rationalization of their decisions, these statements may not be reliable (George and Epstein 1992, 328; Spaeth 1995, 296). If judges include a disproportionate number of facts indicating domestic connections when they decide to assert domestic adjudicative authority (and vice versa), then such selectivity might create bias, exaggerating the effect of the territoriality heuristic. For two reasons, however, my assessment is that this does not seriously threaten my analysis. First, one would expect judges who engage in selective fact reporting as a method of post hoc legal rationalization to selectively state facts that are legally relevant according to the applicable legal doctrine-in this case, facts that are directly relevant to the factors specified by the forum non conveniens doctrine, such as those listed in Appendix B. However, the locus of the transnational activity giving rise to the dispute is not one of those factors. Moreover, my measure of territoriality excludes statements about the location of witnesses and other sources of evidence, which could be used to rationalize decisions since ease of access to witnesses and documents are among the private interest factors specified by the forum non conveniens doctrine. ${ }^{56}$

\footnotetext{
${ }^{56}$ By itself, however, this is only a partial solution because it does not eliminate the risk posed by selective statements of facts about territoriality to justify decisions under the "local interest in localized controversies" factor of forum non conveniens analysis.
} 
Second, a comparison of two different measures of territorial statements in court opinions - one quantitative measure designed to capture selectivity and another qualitative measure designed to be less sensitive to selectivity - have very similar values for decisions to grant forum non conveniens motions and decisions to deny them. The first measure is a percentage equal to the raw number of statements in the court's opinion locating an act or thing giving rise to the litigation outside U.S. territory, divided by the total number of statements locating such an act or thing either inside or outside U.S. territory. This quantitative measure is deliberately sensitive to court opinions that overstate extraterritorial contacts relative to domestic contacts (or vice versa). The second measure is a percentage representing the extent to which the two conceptual elements of the activity giving rise to the litigation are outside U.S. territory: the place of the plaintiff's injury and the place of the defendant's alleged conduct. I coded each element as purely domestic (0), mixed (1), or purely foreign (2), regardless of the total number of related statements about domestic or foreign location, such that their sum can range from 0 out of 4 (0 percent) to 4 out of 4 (100 percent). By disregarding the quantity of territorial statements, this qualitative measure should be less sensitive to factual selectivity. ${ }^{57}$ Thus, to the extent judges are creating post hoc justifications for their decisions by selectively stating facts about territoriality in their opinions, the first measure should be higher than the second for decisions to grant forum non conveniens motions (indicating overstatements of foreign contacts), and lower than the second for decisions to deny them (indicating understatements of foreign contacts).

\section{Table 6. Selectivity in Statements of Territorial Facts in Forum Non Conveniens Opinions}

\begin{tabular}{llccc}
\hline & & \multicolumn{3}{c}{ Measures of Territoriality } \\
& & $\begin{array}{c}\text { Quantitative } \\
\text { Measure }\end{array}$ & Measure & $\begin{array}{c}\text { Paired t-test } \\
(\mathrm{P}>|\mathrm{t}|)\end{array}$ \\
\hline & $\begin{array}{l}\text { Assert Domestic } \\
\text { Adjudicative } \\
\text { Forum Non } \\
\begin{array}{l}\text { Conveniens } \\
\text { Decision }\end{array}\end{array}$ & .538 & .532 & .772 \\
& $\begin{array}{l}\text { Authority } \\
\text { Defer to Foreign } \\
\text { Adjudicative } \\
\text { Authority }\end{array}$ & .711 & .734 & \\
& Total & & & \\
& & & & \\
\hline
\end{tabular}

Table 6 indicates that this is not the case. When U.S. district courts assert domestic adjudicative authority, the quantitative measure is slightly higher on average; and when they defer to foreign adjudicative authority the qualitative measure is slightly higher on average. However, as the t-tests indicate, neither difference is statistically significant. Therefore, my

\footnotetext{
${ }^{57}$ Even if the qualitative measure reduces sensitivity to selective statements of facts, it would still be sensitive to judicial mischaracterization of facts. However, it is reasonable to assume that mischaracterization is uncommon (Hall and Wright 2006, 18). Moreover, even if there is occasional mischaracterization, judges presumably are more willing to be selective than to mischaracterize, which means the quantitative measure should nevertheless be more sensitive than the qualitative measure to efforts to use statements of facts for post hoc rationalization.
} 
assessment is that the possibility of selective statements of territorial facts does not pose a serious threat to my inferences about the influence of the territoriality heuristic.

A second potential threat to my causal inferences arises because my sample includes only decisions that have been published either in the U.S. district courts' official reporter, the Federal Supplement, or electronically in the LexisNexis database. If published forum non conveniens decisions are not representative of the overall population of forum non conveniens decisions, then selection bias may limit the generalizability of my causal inferences to that population. As discussed above, however, the most important decisions for global governance are precisely published decisions, because only they not only affect the litigants in individual cases but also provide information that can more broadly influence the strategic behavior of transnational actors. ${ }^{58}$ Therefore, in the study of transnational judicial governance, the possibility of selection bias caused by differences between published and unpublished decisions is not a central problem because it is not essential to generalize beyond published decisions in the first place. $^{59}$

That said, it is not clear that this form of selection bias is a threat even to causal inferences about the overall population of forum non conveniens decisions. Even if my sample is not representative of the overall population, selection bias, understood as an omitted variable problem (Heckman 1979, 154-155), will threaten my causal inferences only if a determinant of publication has a causal effect on forum non conveniens decisionmaking and is correlated with one or more of my included independent variables (King, Keohane, and Verba 1994, 169). Assessing the threat of selection bias therefore requires an understanding of how U.S. district court judges decide whether or not to publish. Although the determinants of the publication decision are not well understood, there is some evidence that U.S. district court judges are less likely to publish decisions in which the federal government is a party, and that they are more likely to publish cases establishing a new rule of law or in which large companies or law firms are involved, or if they are in the first or second federal judicial circuits (Swenson 2004, 131136). Moreover, one would expect judges to be less likely to publish when they have heavier caseloads (Vladeck and Gulati 2005, 1-5) and more likely to publish decisions that they find more salient (Olson 1992, 796-797). There are not obvious reasons to expect most of these possible determinants of publication to have a causal effect on forum non conveniens

\footnotetext{
${ }^{58}$ Moreover, only published decisions are likely to be used as binding legal precedent—as a practical matter, because attorneys cannot readily research unpublished decisions, and sometimes as a legal matter, when court rules prohibit citation to opinions that are designated as “unpublished” (Gerken 2004). Olson (1992, 795) notes that despite the limitations of reliance on only published decisions, such an approach "may be most justifiable for a researcher who is trying to study efficiently the 'public policy' output of district courts.”

${ }^{59}$ Likewise, case-selection effects do not pose a threat to causal inferences about forum non conveniens decisionmaking. The case-selection effect "refers to the proposition that the parties' selection of litigated or tried cases is not a random sample of the mass of underlying disputes or cases, but instead a biased sample" (Clermont and Eisenberg 1998, 588). Therefore, “win rates reveal something about the set of adjudged cases, and not much about the underlying mass of disputes and cases" (Clermont and Eisenberg 1998, 589). However, this study aims to explain the determinants of forum non conveniens decisionmaking, not to shed light on "the underlying mass of disputes and cases," as important as this is. Although the case-selection effect must be understood to attribute legal meaning to forum non conveniens motion "win rates" (that is, grants of forum non conveniens motions), this is not necessary to make causal inferences about my primary (published forum non conveniens decisions by U.S. district courts) or secondary (all forum non conveniens decisions, whether or not published) populations of interest.
} 
decisionmaking. ${ }^{60}$ However, as discussed above, there are reasons to expect salience to have a negative effect and caseload to have a positive effect on the probability of granting forum non conveniens motions, and these factors also are likely to be highly correlated with the independent variables I include in my model to measure salience and caseload. The possibility of selection bias means that salience and caseload may actually have an effect in the general population of forum non conveniens decisions even though they do not have a statistically significant effect in my sample of published forum non conveniens cases, although the extent of any such bias is difficult to estimate. ${ }^{61}$ In summary, although the possibility of selection bias resulting from skewed publication patterns must be taken seriously (Clermont and Eisenberg 2002, 125-126), my preliminary assessment is that my causal inferences about published forum non conveniens decisions might nevertheless be soundly generalizable to the overall population of forum non conveniens decisions. ${ }^{62}$

\section{Conclusion}

Political scientists and legal scholars have long recognized the important role that domestic courts play in domestic governance, in both the United States and other states (Dahl 1957; Hirschl 2004, 2006; Shapiro 1962, 1981; Stone Sweet 2000; Tate and Vallinder 1995). More recently, international courts are receiving greater scholarly attention for their role in both

\footnotetext{
${ }^{60}$ For example, any effect of federal government, large company, or large law firm involvement would likely depend on whether such a party prefers that the forum non conveniens motion be granted or denied, and the establishment of a new rule of law would not seem to be systematically more or less likely in connection with grants rather than denials of forum non conveniens motions. Likewise, there is no apparent reason to expect membership in the first or seventh circuit to make a U.S. district court judge more or less likely to grant these motions. Other than possible correlations between federal government involvement and my measure of salience (whether there is an issue of federal law) and circuit and caseload, there is no apparent reason to expect these factors to be significantly correlated with independent variables that are included in my model.

${ }^{61}$ Existing research suggests that ideology does not influence publication by the federal courts of appeals (Merritt and Brudney 2001, 98). Consistent with these priors, Swenson $(2004,132)$ finds that the interaction between the ideological direction of the decision and the judge's party has no effect on publication. However, one of the constitutive terms of this interaction, the ideological direction of the decision, does have a statistically significant effect in her model, indicating that conservative decisions are less likely to be published $(2004,132)$. This finding raises the possibility that my sample may under-represent denials of forum non conveniens motions (assuming judges in fact perceive denials as intrinsically more conservative than grants), and that selection bias may limit my ability to generalize my findings about potentially correlated variables (including judges' ideologies and the political environment) to the overall population of forum non conveniens decisions. However, Swenson omits the other constitutive term, the judge's party, from her statistical model $(2004,132)$. The almost inevitable result is that her estimates of the coefficients for the ideological direction of the decision and for the interaction term are biased and inconsistent (Brambor, Clark and Golder 2005, 67). Moreover, the coefficient for a constitutive term only captures the impact it has on the dependent variable when the other constitutive variable equals 0 (and vice versa) (Braumoeller 2004, 809). By omitting the judge's party constitutive term, she in effect forces it to 0 (Braumoeller 2004, 813), but since we do not know whether 0 indicates Democrat or Republican, we do not know whether her finding about the ideological direction of the decision, if valid at all, is capturing its effect on publication when judges are Democrat or when they are Republican. Therefore, although the possibility of selection bias caused by the relationship between the ideological direction of decisions and the decision to publish cannot be eliminated, there does not appear to be sound empirical evidence suggesting that such bias is likely.

${ }^{62}$ In contrast to my causal inferences, however, to attribute legal meaning to my descriptive statistics about the forum non conveniens decisions in my sample, it is absolutely essential to understand the selection process (Clermont and Eisenberg 2002, 137-14). For example, as discussed above, what would seem to be a surprisingly high rate of forum non conveniens dismissals may simply be due to many cases being brought in U.S. district courts by foreign plaintiffs in disputes arising from primarily extraterritorial activity.
} 
international and domestic governance (Alter 2001, 2006; Caporaso and Jupille 2005; Cichowski 2006; Conant 2006; Helfer and Slaughter 1997; Volcansek and Stack 2005). This paper, and the broader project of which it is a part, complements this work by focusing on a largely neglected form of judicial governance: the role of domestic courts in global governance.

But this paper also has broader implications for the study of international relations. Most importantly, it suggests that for scholars of international political economy and global governance to have a satisfactory understanding of how states regulate transnational activity, they cannot ignore domestic institutions, including domestic courts. It reinforces the earlier calls of Shapiro (1993, 267) and Slaughter $(1993,231)$ for international relations scholars to develop a better understanding of private international law, which is the doctrinal counterpart to transnational judicial governance. The paper also has broader implications for the study of judicial decisionmaking. My findings provide empirical support for Slaughter's liberal international law theory: U.S. district court judges indeed appear more likely to defer to the adjudicative authority of other liberal democracies than to the adjudicative authority of other states. My findings also reinforce claims that while the attitudinal and strategic models of judicial decisionmaking do a good job explaining Supreme Court decisions, they may not be as effective when applied to the decisions of lower court judges. At the same time, however, my findings suggest that the legal model may overestimate the ability of busy lower court judges to engage in systematic legal analysis. Although one must generalize with caution, the heuristics model developed in this paper may better describe the decisionmaking process in U.S. district courts than the attitudinal, strategic, and legal models.

I have found that rule-of-law factors appear to predominate in transnational judicial governance, at least in the allocation of adjudicative authority in forum non conveniens decisionmaking. In this sense, my conclusions are optimistic about the possibility of a distinctive role for domestic courts in global governance. However, as indicated by the heuristics model of judicial decisionmaking developed in this paper, my conclusions are also realistic in the sense that they explicitly take into account the limited decisionmaking resources of judges. If transnational judicial governance is based on the rule of law, it is not an ideal-type "law maximizing" rule of law, but a more modest "law satisficing" rule of law. And to the extent my heuristics model is convincing, then barring some combination of increased judicial resources, reduced caseload, or substantial reform of private international law principles to make them far more simple for judges to apply, this modest version of the rule of law is probably all that we can reasonably expect. 
Appendix A: Summary Statistics

\begin{tabular}{lccccc}
\hline Variable & Obs. & Mean & $\begin{array}{c}\text { Std. } \\
\text { Dev. }\end{array}$ & Min. & Max. \\
\hline Deference to Foreign Governance Authority & 210 & .471 & .500 & 0 & 1 \\
Republican Judge & 208 & .548 & .499 & 0 & 1 \\
Republican Environment & 210 & .381 & .487 & 0 & 1 \\
Domestic Plaintiff & 207 & .512 & .501 & 0 & 1 \\
Domestic Defendant & 207 & .469 & .500 & 0 & 1 \\
Foreign State’s GDP (log) & 200 & 12.634 & 1.799 & 5.780 & 15.373 \\
Foreign State’s Military Spending (log) & 189 & 17.987 & 1.676 & 12.635 & 19.937 \\
Liberal Democracy & 203 & .769 & .423 & 0 & 1 \\
Territoriality (Place) & 206 & .524 & .501 & 0 & 1 \\
Territoriality (Contacts) & 208 & .619 & .228 & 0 & 1 \\
Federal Statute & 209 & .330 & .471 & 0 & 1 \\
Political & 209 & .091 & .288 & 0 & 1 \\
Caseload (log) & 208 & 6.131 & .254 & 5.323 & 6.788 \\
& & & & & \\
\hline
\end{tabular}


Whytock 32

\title{
Appendix B: Overview of the Forum Non Conveniens Doctrine
}

\author{
In Piper v. Reyno (1981), the U.S. Supreme Court summarized the forum non conveniens \\ doctrine as follows:
}

[W] hen an alternative forum has jurisdiction to hear the case, and when trial in the chosen forum would 'establish ... oppressiveness and vexation to a defendant ... out of all proportion to plaintiff's convenience,' or when the 'chosen forum [is] inappropriate because of considerations affecting the court's own administrative and legal problems,' the court may, in the exercise of its sound discretion, dismiss the case. To guide trial court discretion, the Court provided a list of 'private interest factors' affecting the convenience of the litigants, and a list of 'public interest factors' affecting the convenience of the forum. ${ }^{63}$

The following is the list of factors to be considered by district courts when deciding whether to dismiss a case on forum non conveniens grounds, excerpted from the Supreme Court's seminal statement of the forum non conveniens doctrine in Gulf Oil v. Gilbert (1947):

\begin{abstract}
If the combination and weight of factors requisite to given results are difficult to forecast or state, those to be considered are not difficult to name. An interest to be considered, and the one likely to be most pressed, is the private interest of the litigant. Important considerations are the relative ease of access to sources of proof; availability of compulsory process for attendance of unwilling, and the cost of obtaining attendance of willing, witnesses; possibility of view of premises, if view would be appropriate to the action; and all other practical problems that make trial of a case easy, expeditious and inexpensive. There may also be questions as to the enforcibility of a judgment if one is obtained. The court will weigh relative advantages and obstacles to fair trial. It is often said that the plaintiff may not, by choice of an inconvenient forum, 'vex,' 'harass,' or 'oppress' the defendant by inflicting upon him expense or trouble not necessary to his own right to pursue his remedy. But unless the balance is strongly in favor of the defendant, the plaintiff's choice of forum should rarely be disturbed.
\end{abstract}

Factors of public interest also have place in applying the doctrine. Administrative difficulties follow for courts when litigation is piled up in congested centers instead of being handled at its origin. Jury duty is a burden that ought not to be imposed upon the people of a community which has no relation to the litigation. In cases which touch the affairs of many persons, there is reason for holding the trial in their view and reach rather than in remote parts of the country where they can learn of it by report only. There is a local interest in having localized controversies decided at home. There is an appropriateness, too, in having the trial of a diversity case in a forum that is at home with the state law that must govern the case, rather than having a court in some other forum untangle problems in conflict of laws, and in law foreign to itself. ${ }^{64}$

Subsequently, in Piper v. Reyno (1981), the Supreme Court stated that “a plaintiff's choice of forum is entitled to greater deference when the plaintiff has chosen the home forum. When the home forum has been chosen, it is reasonable to assume that this choice is convenient. When the plaintiff is foreign, however, this assumption is much less reasonable. Because the central purpose of any forum non conveniens inquiry is to ensure that the trial is convenient, a foreign plaintiff's choice deserves less deference." 65 It also clarified that "[a]t the outset of any forum non conveniens inquiry, the court must determine whether there exists an alternative forum. Ordinarily, this requirement will be satisfied when the defendant is 'amenable to process' in the other jurisdiction. In rare circumstances, however, where the remedy offered by the other forum is clearly unsatisfactory, the other forum may not be an adequate alternative, and the

\footnotetext{
63454 U.S. 235, 241 (citations omitted).

${ }^{64} 330$ U.S. 501, 508-509 (footnotes omitted).

65454 U.S. 235, 266.
} 
initial requirement may not be satisfied. Thus, for example, dismissal would not be appropriate where the alternative forum does not permit litigation of the subject matter of the dispute.”66

The forum non conveniens doctrine thus calls on district courts to make three principal determinations: the level of deference owed to the plaintiff's choice of a U.S. court, the existence of an alternative forum, and the balancing of private and public interest factors. The doctrine explicitly identifies a specific fact that should be the basis for making the first determination: the citizenship of the plaintiff. A district court should give more deference to a U.S. plaintiff's choice of a U.S. court than a foreign plaintiff's choice of a U.S. court. The legal model of judicial decisionmaking would therefore imply the following hypothesis: A district court judge is more likely to grant a motion to dismiss transnational litigation in favor of a foreign court on forum non conveniens grounds if the plaintiff is a foreign citizen rather than a U.S. citizen.

The two other parts of forum non conveniens doctrine do not provide a sound basis for building a legal model of forum non conveniens decisionmaking or generating additional legal model hypotheses. Regarding the second element, the doctrine does not explicitly identify specific facts that should be the basis for determining whether there is an alternative forum. Rather, it raises two subsidiary legal issues: whether the defendant would be subject to the foreign court's jurisdiction (availability) and whether an adequate remedy for the plaintiff is available in the foreign court (adequacy). Segal (1984) addressed similar subsidiary legal issues in his legal model of Supreme Court search and seizure decisionmaking by measuring how the lower court judges in each case resolved these issues. He did not use the Supreme Court's own case-by-case decisions on these issues, such as probable cause, because "we do not know whether the Court's decision on probable cause contributes to its decision . . or merely justifies that decision" (Segal 1984, 894). Unfortunately, this solution is not available for studies of district court forum non conveniens decisionmaking because there are no relevant lower courts.

The third element - the balancing of private and public interest factors — is likewise problematic. The "availability of compulsory process," the "enforcibility of the judgment," and the "law that must govern the case" all raise subsidiary legal issues, raising the same difficulty as the second element. Other factors - "relative ease of access to sources of proof," "view of premises, if view would be appropriate to the action," "all other practical problems," "administrative difficulties ... when litigation is piled up in congested centers instead of being handled at its origin," the community's "relation to the litigation" and whether the controversy is "localized"-do not explicitly identify the specific facts to be considered when weighing each of them. ${ }^{67}$ While some such facts may suggest themselves to district court judges as a matter of common sense or emerge as useful decisionmaking heuristics, measuring them as variables to test a legal model of forum non conveniens is not appropriate because they are not identified by the doctrine itself. In other words, variables for facts that are not explicitly identified in the legal doctrine but nevertheless included because they are deemed relevant by the model-builder would measure the model-builder's interpretation of the doctrine rather than Supreme Court's statement of the doctrine itself.

\footnotetext{
${ }^{66} 454$ U.S. 235, 255 (citations omitted).

${ }^{67}$ The remaining factor — “the cost of obtaining attendance of . . . witnesses” and — does suggest a doctrinally relevant fact. However, this cost is virtually never calculated in district court opinions. Instead, this factor typically is analyzed by considering where the witnesses reside relative to the court.
} 
Although the forum non conveniens doctrine does not lend itself to the development of a comprehensive legal model for predicting the outcomes of forum non conveniens decisions, it does provide the basis for the qualitative analysis of judicial opinions using the method of structured, focused comparison (George and Bennett 2005, chap. 3) to evaluate the extent to which these decisions are based on legal analysis, as the legal model would imply. To structure this comparison, I divided the forum non conveniens doctrine, as set forth in by the Supreme Court in Gilbert v. Gulf Oil and Piper v. Reyno, into the following eleven elements and applied them as described in the body of this paper:

\begin{tabular}{|c|c|c|}
\hline \multicolumn{3}{|c|}{ Elements of Forum Non Conveniens Analysis } \\
\hline Level of Deference & 1 & $\begin{array}{l}\text { Determination of the level of deference owed to the plaintiff's } \\
\text { choice of a U.S. court, based on whether the plaintiff is a U.S. } \\
\text { citizen. }\end{array}$ \\
\hline Alternative Forum & 2 & $\begin{array}{l}\text { Whether the proposed foreign court an available and adequate } \\
\text { alternative. }\end{array}$ \\
\hline Private Interest Factors & & $\begin{array}{l}\text { Relative ease of access to sources of proof. } \\
\text { Relative ease of access to witnesses. } \\
\text { The enforceability of a judgment if one is obtained. } \\
\text { Whether the balance of private interest factors favors the } \\
\text { defendant. }\end{array}$ \\
\hline Public Interest Factors & $\begin{array}{c}7 \\
8 \\
9 \\
10 \\
11\end{array}$ & $\begin{array}{l}\text { Extent of administrative difficulties from court congestion. } \\
\text { Burden of jury duty imposed on people of the community. } \\
\text { Local interest in localized controversies. } \\
\text { Whether the court is at home with the governing law. } \\
\text { Whether the balance of public interest factors favors the } \\
\text { foreign court. }\end{array}$ \\
\hline $\begin{array}{l}\text { Note: I did not count for vie } \\
\text { factually relevant, which me } \\
\text { against the legal model. Th } \\
\text { the case and therefore shoul }\end{array}$ & & $\begin{array}{l}\text { ses or "other" private interest factors, because these will not always be } \\
\text { or them as part of the qualitative analysis would have risked creating bias } \\
\text { e included in this analysis are relevant regardless of the specific facts of } \\
\text { be analyzed in all cases. }\end{array}$ \\
\hline
\end{tabular}




\section{References}

Alter, Karen. 2001. Establishing the Supremacy of European Law: The Making of an International Rule of Law in Europe. Oxford: Oxford University Press.

Alter, Karen A. 2006. "Private Litigants and the New International Courts.” Comparative Political Studies 39 (1) (February 2006): 22-49.

Altman, Douglas G., and J. Martin Bland. 1994. "Diagnostic Tests 3: Receiver Operating Characteristic Plots.” British Medical Journal 309: 188 (July 16, 1994).

Alvarez, José E. 2001. “Do Liberal States Behave Better? A Critique of Slaughter’s Liberal Theory.” European Journal of International Law 12 (2): 183-246.

Bainbridge, Stephen M., and G. Mitu Gulati. 2002. "How Do Judges Maximize? (The Same Way Everybody Else Does-Boundedly): Rules of Thumb in Securities Fraud Opinions.” Emory Law Journal 51: 83-151.

Baum, Lawrence. 1994. “What Judges Want: Judges’ Goals and Judicial Behavior.” Political Research Quarterly 47 (3) (Sept. 1994): 749-768.

Berman, Paul Schiff. 2005. “Towards a Cosmopolitan Vision of Conflict of Laws: Redefining Governmental Interests in a Global Era.” University of Pennsylvania Law Review 153: 1819-1882.

Bermann, George A. 2003. Transnational Litigation. St. Paul, MN: West.

Bhattacharya , Utpal, Neal E. Galpin, and Bruce Haslem. 2006. “The Home Court Advantage in International Corporate Litigation,” unpublished manuscript, available at http://ssrn.com/abstract=509008.

Born, Gary B. 1996. International Civil Litigation in United States Courts: Commentary and Materials, Third Edition. The Hague: Kluwer Law International.

Brambor, Thomas, William Roberts Clark, and Matt Goldner. 2006. “Understanding Interactions Models: Improving Empirical Analyses.” Political Analysis 14 (1) (Winter 2006): 63-82.

Braumoeller, Bear F. 2004. “Hypothesis Testing and Multiplicative Interaction Terms.” International Organization 58 (Fall 2004): 807-820.

Brilmayer, Lea. 1991. Conflict of Laws: Foundations and Future Directions. Boston: Little Brown.

Burley, Anne-Marie. 1992. "Law among Liberal States: Liberal Internationalism and the Act of State Doctrine.” Columbia Law Review 92 (8) (December 1992): 1907-1996.

Burley, Anne-Marie, and Walter Mattli. 1993. “Europe Before the Court: A Political Theory of Legal Integration.” International Organization 47 (1) (Winter 1993): 41-76.

Busch, Marc L., and Eric Reinhardt. 2000. "Bargaining in the Shadow of the Law: Early Settlement in GATT/WTO Disputes.” Fordham International Law Journal 24: 158-172.

Buxbaum, Hannah L. 2006. “Transnational Regulatory Litigation.” Virginia Journal of International Law 46 (2): 251-317.

Caporaso, James A., and Joseph Jupille. 2005. “The Second Image Overruled: European Law, Domestic Institutions, and British Sovereignty.” Available at http://sobek.colorado.edu/ jupille/research/research.htm. 
Carp, Robert A., Ronald Stidham, and Kenneth L. Manning. 2004. Judicial Process in America. $6^{\text {th }}$ ed. Washington, DC: CQ Press.

Carter, Barry E., and Phillip R. Trimble. 1991. International Law. Boston: Little, Brown and Company.

Cichowski, Rachel A. 2006. “Courts, Democracy, and Governance.” Comparative Political Studies 39 (1) (February 2006): 3-21.

Clermont, Kevin M. 2004. "The Role of Private International Law in the United States: Beating the Not-Quite-Dead Horse of Jurisdiction,” Cornell Law School Research paper No. 04-012, available at

http://ssrn.com/abstract=588321 (September 4, 2004).

Clermont, Kevin M., and Theodore Eisenberg. 1995. “Exorcising the Evil of Forum-Shopping.” Cornell Law Review 80: 1507-1535.

Clermont, Kevin M., and Theodore Eisenberg. 1996. “Xenophilia in American Courts.” Harvard Law Review 109

(5) (March 1996): 1120-1143.

Clermont, Kevin M., and Theodore Eisenberg. 1998. "Do Case Outcomes Really Reveal Anything about the Legal System? Win Rates and Removal Jurisdiction.” Cornell Law Review 83: 581-607.

Clermont, Kevin M., and Theodore Eisenberg. 2002. “Litigation Realities.” Cornell Law Review 88: 119-154.

Clermont, Kevin M., and Theodore Eisenberg. 2006. "Xenophilia or Xenophobia in American Courts? Before and After 9/11.” Cornell Law School Research Paper No. 06-018, available at http://ssrn.com/abstract=923595.

Collier, David, James Mahoney, and Jason Seawright. 2004. "Claiming Too Much: Warnings about Selection Bias.” In Rethinking Social Inquiry: Diverse Tools, Shared Traditions, eds. Henry E. Brady and David Collier. Lanham, MD: Rowman \& Littlefield Publishers.

Conant, Lisa. 2006. "Individuals, Courts, and the Development of European Social Rights.” Comparative Political Studies 39 (1) (February 2006): 76-100.

Cooter, Robert, and Stephen Marks, with Robert Mnookin. 1982. "Bargaining in the Shadow of the Law: A Testable Model of Strategic Behavior.” Journal of Legal Studies XI (June 1982): 225-251.

Cooter, Robert, and Thomas Ulen. 2000. Law and Economics (Third Edition). Reading, MA: Addison Wesley Longman, Inc.

Dahl, Robert. 1957. "Decision-Making in a Democracy: The Role of the Supreme Court as National Policy-Maker.” Journal of Public Law 6 (2) (Fall 1957): 279-295.

Davis, Jeffrey. 2006. “Justice Without Borders: Human Rights Cases in U.S. Courts.” Law \& Policy 28 (1) (January 2006): 60-82.

Dezalay, Yves, and Bryant G. Garth. 1996. Dealing in Virtue: International Commercial Arbitration and the Construction of a Transnational Legal Order. Chicago: University of Chicago Press.

Epstein, Lee, and Jack Knight. 1998. The Choices Justices Make. Washington, DC: CQ Press.

Evans, Peter, Harold K. Jacobson, and Robert D. Putnam, eds. 1993. Double-Edged Diplomacy: International Bargaining and Domestic Politics. Berkeley: University of California Press.

Federal Judicial Center. 2005. Federal Court Cases: Integrated Data Base, 2001 [Computer file]. $3^{\text {rd }}$ ICPSR version. Washington, DC: Federal Judicial Center [producer], 2001. Ann arbor, MI: Inter-university Consortium for Political and Social Research [distributor]. 
Federal Judicial Center. 2007. “Biographical Directory of Federal Judges.” Available at http://www.fjc.gov/public/home.nsf/hisj.

Freedom House. 2006. “Freedom in the World 2006.” Database accessible at http://www.freedomhouse.org/.

Frieden, Jeffry, and Lisa L. Martin. 2002. “International Political Economy: Global and Domestic Interactions.” In Political Science: The State of the Discipline, eds. Ira Katznelson and Helen V. Milner. New York: W. W. Norton. Pp. 118-146.

Geddes, Barbara. 2003. Paradigms and Sand Castles: Theory Building and Research Design in Comparative Politics. Ann Arbor: University of Michigan Press.

George, Alexander L., and Andrew Bennett. 2005. Case Studies and Theory Development in the Social Sciences. Cambridge: MIT Press.

George, Tracey E. 1998. “Developing a Positive Theory of Decisionmaking on U.S. Courts of Appeals.” Ohio State Law Journal 58: 1635-1696.

George, Tracey E., and Lee Epstein. 1992. “On the Nature of Supreme Court Decision Making.” American Political Science Review 86 (2) (June 1992): 323-337.

Gerken, Joseph L. 2004. “A Librarian’s Guide to Unpublished Judicial Opinions.” Law Library Journal 96 (3): 475501.

Gillman, Howard. 1999. "The Court as an Idea, Not a Building (or Game): Interpretive Institutionalism and the Analysis of Supreme Court Decision-Making.” In Cornell W. Clayton and Howard Gillman, eds., Supreme Court Decision-Making: New Institutionalist Approaches. Chicago: University of Chicago Press. Pp. 65-87.

Gillman, Howard. 2001. "What's Law Got to Do with It? Judicial Behavioralists Test the 'Legal Model’ of Judicial Decision Making.” Law and Social Inquiry 26 (2) (Spring 2001): 465-504.

Goldsmith, Jack L., and Eric A. Posner. 2005. The Limits of International Law. Oxford: Oxford University Press.

Gruber, Lloyd. 2000. Ruling the World: Power Politics and the Rise of Supranational Institutions. Princeton: Princeton University Press.

Guthrie, Chris, Jeffrey J. Rachlinksi, and Andrew J. Wistrich. 2001. “Inside the Judicial Mind.” Cornell Law Review 86 (): 777-830.

Guzman, Andrew T., and Beth A. Simmons. 2005. "Power Plays and Capacity Constraints: The Selection of Defendants in World Trade Organization Disputes.” Journal of Legal Studies 34 (2) (June 2005): 557-598.

Hall, Mark A., and Ronald F. Wright. 2006. “Systematic Content Analysis of Judicial Opinions,” unpublished manuscript available at http://ssrn.com/abstrct=913336 (July 2006).

Hamilton, Lawrence C. 2004. Statistics with Stata. Belmont, CA: Wadsworth Group.

Heckman, James J. 1979. “Sample Selection Bias as a Specification Error.” Econometrica 47 (1) January 1979): 153-161.

Helfer, Laurence R., and Anne-Marie Slaughter. 1997. "Toward a Theory of Effective Supranational Adjudication.” Yale Law Journal 107 (2) (November 1997): 273-391. 
Hettinger, Virginia A., Stefanie A. Lindquist, and Wendy L. Martinek. 2004. "Comparing Attitudinal and Strategic Accounts of Dissenting Behavior on the U.S. Courts of Appeals.” American Journal of Political Science 48 (1) (January 2004): 123-137.

Hirschl, Ran. 2004. Towards Juristocracy: The Origins and Consequences of the New Constitutionalism. Cambridge, MA: Cambridge University Press.

Hirschl, Ran. 2006. “The New Constitutionalism and the Judicialization of Pure Politics Worldwide.” Fordham Law Review 75: 721-754.

Ikenberry, G. John. 2001. After Victory: Institutions, Strategic Restraint, and the Rebuilding of Order after Major Wars. Princeton: Princeton University Press.

Jones, Bryan D. 1999. “Bounded Rationality.” Annual Review of Political Science 2: 297-321.

Juenger, Friedrich K. 2005. Choice of Law and Multistate Justice (Special Edition). Ardsley, NY: Transnational Publishers.

Kahn, Ronald. 1999. "Institutional Norms and Supreme Court Decision-Making.” In Supreme Court DecisionMaking: New Institutionalist Approaches, eds. Cornell W. Clayton and Howard Gillman. Chicago: University of Chicago Press. Pp. 175-198.

Kahneman, Daniel, and Shane Frederick. 2005. “A Model of Heuristic Judgment. In The Cambridge Handbook of Thinking and Reasoning, eds. Keith J. Holyoak \& Robert G. Morrison. Cambridge: Cambridge University Press. Pp. 267-293.

Kaplow, Louis, and Steven Shavell. 1999. "Economic Analysis of Law.” National Bureau of Economic Research, Working Paper 6960, February 1999, available at www.nber.org/papers/w6960.

Keohane, Robert O., and Lisa L. Martin. 2003. “Institutional Theory as Research Program.” In Progress in International Relations Theory: Appraising the Field, eds. Colin Elman and Miriam Fendius Elman. Cambridge, MA: MIT Press.

Keohane, Robert O., and Joseph S. Nye. 1974. "Transgovernmental Relations and International Organizations.” World Politics 27 (1) (October 1974): 39-62.

King, Gary, Robert O. Keohane, and Sidney Verba. 1994. Designing Social Inquiry: Scientific Inference in Qualitative Research. Princeton, NJ: Princeton University Press.

Koremenos, Barbara. 2005. “Contracting around International Uncertainty.” American Political Science Review 99 (4) (November 2005): 549-565.

Koremenos, Barbara, Charles Lipson \& Duncan Snidal. 2001. “The Rational Design of Institutions.” International Organization 55 (4): 761-799.

Krasner, Stephen D. 1999. Sovereignty: Organized Hypocrisy. Princeton, NJ: Princeton University Press.

Lake, David A., and Robert Powell. 1999. “International Relations: A Strategic-Choice Approach.” In David A. Lake and Robert Powell, eds., Strategic Choice and International Relations. Princeton, NJ: Princeton University Press. Pp. 3-38.

Long, J. Scott, and Jeremy Freese. 2006. Regression Models for Categorical Dependent Variables Using Stata (Second Edition). College Station, TX: Stata Press.

March, James G., and Johan P. Olsen. 1998. “The Institutional Dynamics of International Political Orders.” International Security 52 (4) (Autumn 1998): 943-969. 
Martin, Lisa L., and Beth A. Simmons. 1998. “Theories and Empirical Studies of International Institutions.” International Organization 52 (4) (Autumn 1998): 729-757.

Martinek, Wendy L. 2005. “The Lower Federal Court Confirmation Database 1977-2004.” Available at http://www.binghamton.edu/cdp/lfccd.htm (last update May 23, 2005).

Mattli, Walter. 2001. "Private Justice in a Global Economy: From Litigation to Arbitration.” International Organization 55 (4) (Autumn 2001): 919-947.

Mearsheimer, John J. 2001. The Tragedy of Great Power Politics. New York: W. W. Norton.

Merritt, Deborah Jones, and James J. Brudney. 2001. "Stalking Secret Law: What Predicts Publication in the United States Courts of Appeals.” Vanderbilt Law Review 54 (1): 69-

Michaels, Ralf. 2004. “Territorial Jurisdiction after Territoriality.” In Piet Jan Slot \& Mielle Bulterman, eds., Globalization and Jurisdiction. Hague: Kluwer Law International. Pp. 105-130.

Milner, Helen. 1998. "Rationalizing Politics: The Emerging Synthesis of International, American, and Comparative Politics.” International Organization 52 (4): 759-786.

Moore, Kimberly A. 2003. “Xenophobia in American Courts.” Northwestern University Law Review 97 (): $1497-$

Moravcsik, Andrew. 1997. “Taking Preferences Seriously: A Liberal Theory of International Politics.” International Organization 51 (4):513-553.

Morgenthau, Hans J. 1978. Politics among Nations: The Struggle for Power and Peace (Fifth Edition, Revised). New York: Alfred A. Knopf.

Murphy, Walter F., C. Herman Pritchett, and Lee Epstein. 2002. Courts, Judges, and Politics: An Introduction to the Judicial Process. $5^{\text {th }}$ ed. Boston: McGraw-Hill.

Norman, George, and Joel P. Trachtman. 2005. “The Customary International Law Game.” American Society of International Law 99 (3) (July 2005): 541-580.

O’Hara, Erin A., and Larry E. Ribstein. 1999. “Conflict of Laws and Choice of Law.” In Boudewijn Bouckaert and Gerrit De Geest, eds., Encyclopedia of Law and Economics. Cheltenham, U.K.: 1996-2000. Available at http://encyclo.findlaw.com/.

Olson, Susan M. 1992. “Studying Federal District Courts Through Published Cases: A Research Note.” Justice System Journal 15 (3): 782-800.

Pew Research Center for the People and the Press. 20051. "Beyond Red vs. Blue: Republicans Divided about Role of Government-Democrats by Social and Personal Values,” released May 10, 2005, available at http://peoplepress.org/reports/display.php3?ReportID=242.

Pew Research Center for the People and the Press. 2005b. “Opinion Leaders Turn Cautious, Public Looks Homeward: America’s Place in the World,” released November 17, 2005, available at http://peoplepress.org/reports/display.php3?ReportID=263.

Posner, Richard A. 1993. "What Do Judges and Justices Maximize? (The Same Thing Everybody Else Does)." Supreme Court Economic Review 3: 1-41.

Putnam, Robert D. 1988. “Diplomacy and Domestic Politics: The Logic of Two-Level Games.” International Organization 42 (3) (Summer 1988): 427-460. 
Putnam, Tonya L. 2006. “Courts Without Borders? Extraterritoriality as a Mechanism for Global Governance.” Paper presented at the annual meeting of the International Studies Association, San Diego, CA, March 22, 2006.

Raustiala, Kal. 2002. “The Architecture of International Cooperation: Transgovernmental Networks and the Future of International Law.” Virginia Journal of International Law 43 (Fall): 1-92.

Raustiala, Kal. 2005. “Form and Substance in International Agreements.” American Journal of International Law. 99 (3) (July 2005): 581-614.

Raustiala, Kal. 2006. “The Evolution of Territoriality: International Relations and International Law.” In Miles Kahler \& Barbara Walter, eds., Globalization, Territoriality, and Conflict. Cambridge: Cambridge University Press. Pp.

Reisman, W. Michael, Mahnoush H. Arsanjani, Siegfried Wiessner, and Gayl S. Westerman. 2004. International Law in Contemporary Perspective. New York, NY: Foundation Press.

Rohde, David W., and Harold J. Spaeth. 1976. Supreme Court Decisionmaking. San Francisco: W. H. Freeman and Company.

Russett, Bruce, and John Oneal. 2001. Triangulating Peace: Democracy, Interdependence, and International Organizations. New York, NY: W. W. Norton \& Company.

Sandholtz, Wayne, and Alec Stone Sweet. 2004. “Law, Politics, and International Governance.” In Christian ReusSmit, ed., The Politics of International Law. Cambridge: Cambridge University Press. Pp. 238-271.

Scoles, Eugene F., Peter Hay, Patrick J. Borchers, and Symeon C. Symeonides. 2004. Conflict of Laws (Fourth Edition). St. Paul, MN: West.

Segal, Jeffrey A. 1984. "Predicting Supreme Court Cases Probabilistically: The Search and Seizure Cases, 19621981.” American Political Science Review 78 (4) (December 1984): 891-900.

Segal, Jeffrey A. 1986. "Supreme Court Justices as Human Decision Makers: An Individual-Level Analysis of Search and Seizure Cases.” Journal of Politics 48 (4) (Nov. 1986): 938-955.

Segal, Jeffrey A., Donald R. Songer, and Charles M. Cameron. 1995. "Decision Making on the U.S. Courts of Appeals.” In Lee Epstein, ed., Contemplating Courts. Washington, DC: Congressional Quarterly Press. Pp. $296-314$.

Segal, Jeffrey A., and Harold J. Spaeth. 2002. The Supreme Court and the Attitudinal Model Revisited. Cambridge: Cambridge University Press.

Shapiro, Martin. 1962. The Supreme Court and Public Policy. Glenview, IL: Scott, Foresman.

Shapiro, Martin. 1972. "From Public Law to Public Policy, or the 'Public' in 'Public Law.'” PS (5) (4) (Autumn 1972): 410-418.

Shapiro, Martin. 1981. Courts: A Comparative and Political Analysis. Chicago: University of Chicago Press.

Shapiro, Martin. 1993. "Public Law and Judicial Politics.” In Ada W. Finifter, ed., Political Science: The State of the Discipline II. Washington, DC: American Political Science Association: 365-381.

Simmons, Beth A. 2000. “International Law and State Behavior.” American Political Science Review 94 (December): 819-835.

Simmons, Beth A., and Daniel J. Hopkins. 2005. “The Constraining Power of International Treaties: Theory and Methods.” American Political Science Review 99 (4) (November 2005): 623-631. 
Simon, Herbert A. 1985. "Human Nature in Politics: The Dialogue of Psychology with Political Science.” American Political Science Review 79 (2) (June 1985): 293-304.

Slaughter Burley, Anne-Marie. 1993. "International Law and International Relations Theory: A Dual Agenda.” American Journal of International Law 87: 205-239.

Slaughter, Anne-Marie. 1994. “A Typology of Transjudicial Communication.” University of Richmond Law Review 29: 99-137.

Slaughter, Anne-Marie. 1995. "International Law in a World of Liberal States.” European Journal of International Law 6: 503-538.

Slaughter, Anne-Marie. 2004. A New World Order. Princeton, NJ: Princeton University Press.

Slaughter, Anne-Marie, and David Zaring. 2006. "Networking Goes International: An Update.” Annual Review of Law and Social Science 2: 211-229.

Spaeth, Harold J. 1995. “The Attitudinal Model.” In Lee Epstein, ed., Contemplating Courts. Washington, DC: Congressional Quarterly Press. Pp. 296-314.

Stipanowich, Thomas J. 2004. “ADR and the 'Vanishing Trial': The Growth and Impact of 'Alternative Dispute Resolution.’” Journal of Empirical Legal Studies 1 (3) (November 2004): 843-912.

Stone Sweet, Alec, and Thomas L. Brunell. 1998. "Constructing a Supranational Constitution: Dispute Resolution and Governance in the European Community.” American Political Science Review 92 (1) (March 1998): 63-81.

Stone Sweet, Alec. 2000. Governing with Judges: Constitutional Politics in Europe. Oxford: Oxford University Press.

Stone Sweet, Alec. 2006. “The New Lex Mercatoria and Transnational Governance.” Journal of European Public Policy 13 (5) (August 2006): 627-646.

Sweeney, Joseph Modeste, Covey T. Oliver, and Noyes E. Leech. 1988. Cases and Materials on the International Legal System (Third Edition). Westbury, NY: Foundation Press.

Swenson, Karen. 2004. “Federal District Court Judges and the Decision to Publish.” Justice System Journal 25 (2): 121-142.

Symeonides, Symeon C., Wendy Collins Perdue, and Arthur T. von Mehren. 2003. Conflict of Laws: American, Comparative, International. St. Paul, MN: West.

Tate, C. Neal, and Torbjörn Vallinder. 1995. The Global Expansion of Judicial Power. New York: New York University Press.

Tomz, Michael, Jason Wittenberg, and Gary King. 2001. CLARIFY: Software for Interpreting and Presenting Statistical Results. Version 2.0 Cambridge, MA: Harvard University, June 1. http://gking.harvard.edu.

Unah, Isaac. 1998. The Courts of International Trade: Judicial Specialization, Expertise, and Bureaucratic PolicyMaking. Ann Arbor: University of Michigan Press.

Unah, Isaac, and Ange-Marie Hancock. 2006. "U.S. Supreme Court Decision Making, Case Salience, and the Attitudinal Model.” Law \& Policy 28 (3) (July 2006): 295-320.

Vladeck, David C., and Mitu Gulati. 205. "Judicial Triage: Reflections on the Debate Over Unpublished Opinions.” Washington \& Lee Law Review 62 (): 1667-1708. 
Volcansek, Mary L., and John F. Stack, Jr. 2005. “Judicialization and Sovereignty.” In Courts Crossing Borders: Blurring the Lines of Sovereignty, eds. Mary L. Volcansek and John F. Stack, Jr. Durham, NC: Carolina Academic Press. Pp. 11-21.

Von Stein, Jana. 2005. “Do Treaties Constrain or Screen? Selection Bias and Treaty Compliance.” American Political Science Review 99 (4) (November 2005): 611-622.

Wai, Robert. 2002. “Transnational Liftoff and Juridical Touchdown: The Regulatory Function of Private International Law in an Era of Globalization.” Columbia Journal of Transnational Law 40: 209-274.

Wai, Robert. 2005a. “Transnational Private Law and Private Ordering in a Contested Global Society.” Harvard International Law Journal 46 (2) (Summer 2005): 471-486.

Wai, Robert. 2005b. “Transnational Private Litigation and Transnational Governance.” In Criticizing Global Governance, eds. Markus Lederer and Philipp S. Müller. New York, NY: Palgrave Macmillan. Pp. $243-261$.

Waltz, Kenneth N. 1979. Theory of International Politics. Reading, MA: Addison-Wesley Publishing Company.

Whincop, Michael J., and Mary Keyes. 2001. Policy and Pragmatism in the Conflict of Laws. Burlington, VT: Ashgate.

Whytock, Christopher A. 2005. “A Rational Design Theory of Transgovernmentalism: The Case of E.U.-U.S. Merger Review Cooperation.” Boston University International Law Journal 23 (1) (Spring 2005): 1-53.

Whytock, Christopher A. 2006a. “Domestic Courts and Global Governance,” August 11, 2006, available at http://ssrn.com/abstract=923907.

Whytock, Christopher A. 2006b. "Domestic Courts and Global Governance: Forum Non Conveniens and Judicial Allocation of Conflict Resolution Authority,” presented at the Annual Conference of the Law and Society Association, Baltimore, Maryland, July 6-9, 2006.

Whytock, Christopher A. 2006c. "Foreign Law, Domestic Courts, and World Politics,” presented at the annual conference of the International Studies Association, San Diego, California, March 22-25, 2006.

Wright, Charles Alan, Arthur R. Miller, and Edward H. Cooper. 2007. Federal Practice and Procedure: Jurisdiction (Volume 14D). St. Paul, MN: Thomson/West. 